\title{
ADAMTS13 gene mutations influence ADAMTS13 conformation and disease age-onset in the French cohort of Upshaw-Schulman syndrome.
}

\author{
Running head: French cohort of Upshaw-Schulman syndrome
}

Bérangère S. Joly1,2, Pierre Boisseau, Elien Roose4, Alain Stepanian1,2, Nathalie Biebuyck5, Julien Hogan6, François Provot7, Yahsou Delmas8, Céline Garrec3, Karen Vanhoorelbeke4, Paul Coppos, Agnès Veyradier 1,2 ; on behalf of the French Reference Center for Thrombotic Microangiopathies.

1 EA3518, Institut Universitaire d'Hématologie, Université Paris Diderot, Hôpital Saint-Louis, Assistance Publique - Hôpitaux de Paris, Paris, France

2 Service d'Hématologie biologique, Université Paris Diderot, Hôpital Lariboisière, Assistance Publique - Hôpitaux de Paris, Paris, France

3 Service de Génétique médicale, Hôpital Hôtel-Dieu, CHU de Nantes, Nantes, France

4 Laboratory for Thrombosis Research, IRF Life Sciences, KU Leuven Kulak Campus Kortrijk, Kortrijk, Belgium

5 Service de néphrologie pédiatrique, Hôpital Necker, Assistance Publique - Hôpitaux de Paris, Paris, France

6 Service de néphrologie pédiatrique, Hôpital Robert Debré, Assistance Publique - Hôpitaux de Paris, Paris, France

7 Service de néphrologie, CHRU de Lille, Lille, France

8 Service de néphrologie, CHU Pellegrin, Bordeaux, France

9 Département d'Hématologie Clinique, Université Pierre et Marie Curie, Hôpital Saint-Antoine, Assistance Publique - Hôpitaux de Paris, Paris, France

BS Joly and P. Boisseau contributed equally to this work.

Corresponding author:

Professor Agnès Veyradier, MD, PhD

Service d'Hématologie biologique

Hôpital Lariboisière

2, rue Ambroise Paré

75010 Paris

France

Tel: +33149956411

Fax: +33149956397

Email: agnes.veyradier@aphp.fr

4626 words

52 references

4 tables +4 figures

Abstract 250 words 


\section{Extra Table}

\section{What is known on this topic}

1. Upshaw-Schulman syndrome (USS) is the inherited form of thrombotic thrombocytopenic purpura (TTP) linked to ADAMTS13 gene sequence variations

2. USS is characterized by a great clinical, phenotypic and genotypic heterogeneity.

3. In healthy individuals, ADAMTS13 circulates in a folded conformation where CUB domains interact with the spacer domain. The spacer-CUB interaction is abrogated when ADAMTS13 is conformationally activated.

\section{What this paper adds}

1. We performed a cohort study of 56 patients with a child-onset or an adult-onset USS from the French TTP registry.

2. Age-onset of USS defines two distinct clinical, biological and molecular entities.

3. USS-related ADAMTS13 sequence variations modify both ADAMTS13 conformation and ADAMTS13 allosteric activation. 


\section{Abstract}

Background. Congenital thrombotic thrombocytopenic purpura (TTP) or Upshaw-Schulman syndrome (USS) is a rare, life-threatening, inherited thrombotic microangiopathy (TMA). USS is mostly due to biallelic recessive sequence variations of ADAMTS13 gene inducing a severe ADAMTS13 deficiency (activity <10 IU/dL). In healthy individuals, ADAMTS13 circulates in a folded conformation where CUB domains interact with the spacer domain. The spacer-CUB interaction is abrogated when ADAMTS13 is conformationally activated.

Objectives. To evaluate the influence of ADAMTS13 sequence variations on both clinical/biological phenotype and ADAMTS13 conformation in USS.

Patients/Methods: All USS patients from the French registry for TMAs (January 1st 2000 to June 1 st 2017) were investigated for ADAMTS13 genotype, phenotype (activity, antigen and autoantibodies) and conformation. Clinical records were analyzed (inaugural acute TTP and follow-up). Child-onset USS was compared to adult-onset USS.

Results. 56 USS patients from 51 families (34 child-onset and 22 adult-onset cases) were enrolled. Child-onset USS was characterized by a large panel of ADAMTS13 sequence variations ( $n=43$ ), spread all over ADAMTS13 gene and not correlated with either clinical features or plasmatic ADAMTS13 parameters. In contrast, adult-onset USS, consisting exclusively in pregnancy-induced TTP, included a smaller and distinct panel of ADAMTS13 sequence variations $(n=20)$ because of one mutation (p.Arg1060Trp) present in $82 \%$ of patients. ADAMTS13 conformation was studied in 16 USS patients (5 child-onset and 11 adult-onset USS, encompassing 16 distinct ADAMTS13 sequence variations) whose ADAMTS13 antigen levels were detectable: 14 patients/16 (87.5\%) exhibited abnormalities of ADAMTS13 conformation.

Conclusion. In USS, age-onset defines two entities and ADAMTS13 sequence variations modify ADAMTS13 conformation.

\section{Key words}

ADAMTS13 - Thrombotic thrombocytopenic purpura - Upshaw-Schulman syndrome - Von Willebrand factor - Rare disease 


\section{Introduction}

Thrombotic thrombocytopenic purpura (TTP) is a rare (annual prevalence $\sim 10$ cases per million), relapsing and life-threatening thrombotic microangiopathy (TMA) occurring mostly during adulthood ( $\sim 90 \%$ of all TTP cases).1-3 Clinically, acute phases of TTP are defined by a microangiopathic mechanical hemolytic anemia, a severe thrombocytopenia that may be associated with systemic visceral ischemia. TTP pathophysiology is based on a severe functional deficiency (activity $<10 \mathrm{IU} / \mathrm{dL}$ ) of ADAMTS13 (A Disintegrin and Metalloprotease with ThromboSpondin type 1 repeats, member 13), the specific von Willebrand factor- (VWF) cleaving protease.4,5 ADAMTS13 severe deficiency leads to the accumulation of hyperadhesive ultralarge VWF multimers inducing the spontaneous formation of platelet-rich microthrombi within arterioles and capillaries.4,5 The mechanism for severe ADAMTS13 deficiency is mostly acquired via ADAMTS13 autoantibodies and leads to the autoimmune TTP representing $\sim 95 \%$ of cases. 2,5 More rarely, ADAMTS13 severe deficiency is genetically inherited, mostly via biallelic mutations of ADAMTS13 gene or, in very rare cases, via monoallelic mutations associated with a cluster of single nucleotid polymorphism (SNPs), and leads to the congenital TTP also named Upshaw-Schulman syndrome (USS, OMIM \#274150) and representing $5 \%$ of cases.3,6 So far, about 200 USS cases involving 180 distinct ADAMTS13 sequence variations have been described worldwide thanks to the first report of ADAMTS13 sequence variations, 7 to the international hereditary TTP registry (www.ttpregistry.net) and to national USS registries.8-15 USS is more frequent among child-onset TTP when compared to adult-onset TTP (about one third of cases versus less than $5 \%$ of cases, respectively) 6,16 and its clinical presentation is significantly different as a function of its ageonset. Child-onset USS usually starts in the neonatal period with hematological features and severe jaundice.12,17 In contrast, almost all cases of adult-onset USS are unmasked during the first pregnancy of childbearing age women whose disease was silent during childhood.14,18-22 These two peaks of ageonset of USS reflect a variable penetrance of the different ADAMTS13 sequence variations. Moreover, in vitro and in silico studies of some ADAMTS13 sequence variations identified in USS patients have confirmed their deleterious effect on the function, the synthesis or the secretion of ADAMTS13.11,23-28 More recently, ADAMTS13 structure/function relationship was further elucidated as ADAMTS13 was shown to undergo a physiological conformational change inducing its functional activation: upon interaction with VWF D4-CK domains, ADAMTS13 switches from a folded "closed" conformation (based on an auto-inhibitory CUB-spacer domain interaction and defining a basic state) to an unfolded "open" 
conformation.29-34 In physiologic conditions, this conformation shift is transitory and allows the unmasking of exosites of ADAMTS13 (active state) and consequently, the enhancing of ADAMTS13 activity towards its VWF substrate. In a very recent work, Roose and collaborators developed an original ELISA to distinguish between folded versus open ADAMTS13 conformation.35 However, it is still unknown if sequence variations of ADAMTS13 gene observed in USS may also influence ADAMTS13 conformation. Identifying such mutations might shed more light on the mechanism for conformational activation of ADAMTS13.

In the present study based on our 18-year experience of the French Reference Center for TMA, we focused on 56 French patients with either child- or adult-onset USS. The aim of this study was to evaluate the influence of ADAMTS13 sequence variations on both USS clinical/biological phenotype and ADAMTS13 conformation using two main objectives: firstly, to provide a demographic and a clinical picture of USS at presentation and during the long-term follow-up; secondly, to analyze both ADAMTS13 genotype and phenotype including ADAMTS13 conformation. We show that age-onset defines two distinct entities of USS and that ADAMTS13 sequence variations may modify ADAMTS13 conformation.

\section{Patients, materials and methods}

\section{Patients}

Since 2000 in France, all patients with a presumptive diagnosis of TMA (microangiopathic hemolytic anemia, severe thrombocytopenia and organ ischemia) have been enrolled prospectively and consecutively in the national Registry of the French Reference Center for TMA, qualified by the National Plan for Rare Diseases of the French Health Ministry.36 First, a cross-sectional analysis of the French TMA registry was performed retrospectively from January 1st 2000 to June 1 st 2017 to identify patients with USS using the following inclusion criteria: i) a first TMA episode occurring before age 18 for childonset USS and after age 18 for adult-onset USS; ii) the absence of anti-ADAMTS13 autoantibodies associated with both an ADAMTS13 activity $<10 \mathrm{IU} / \mathrm{dL}$ during acute TTP episodes and an ADAMTS13 activity $<20 \mathrm{IU} / \mathrm{dL}$ during remission phases; iii) the presence of two ADAMTS13 gene sequence variations different from SNPs, or the presence of one ADAMTS13 gene sequence variation associated with several SNPs. Then, medical records were extensively reviewed to collect clinical and biological data, during both the initial acute phase and the follow-up, with a standardized form. Remission was defined by a complete response to treatment with no further thrombocytopenia or clinical worsening 
occurred during at least 30 days after the first day of platelet count recovery. Relapse was defined as the reappearance of clinical manifestations or thrombocytopenia with no other identifiable cause after achieving a durable remission, or both. 37 The ADAMTS13 phenotypic/genotypic data of the child-onset USS patients were compared to those of the adult-onset USS patients.

Written informed consent was obtained from each patient and/or his/her parents according to the Declaration of Helsinki; the study was approved by the Ethics Committee of Hospital Pitié-Salpêtrière and Hospital Saint-Antoine (Paris, France). No patient refused enrolment in the study, registered with ClinicalTrials.gov, number NCT00426686.

\section{Blood collection}

Venous blood was collected at time of enrolment (inaugural TTP episode) before any treatment, and during follow-up, into 1:10 final volume of $3.8 \%$ sodium citrate; platelet-poor plasma was obtained as previously described. 38 Plasma was frozen at $-20^{\circ} \mathrm{C}$ until transport to the central laboratory.

\section{ADAMTS13 phenotypic assays}

ADAMTS13 activity was measured using 3 reference methods: FRETS-VWF73 (Peptide Institute Inc, Osaka, Japan),39 full-length VWF ELISA 40 and full-length VWF CBA.41 Calibration curves were performed using a normal pooled plasma (NPP) from 50 healthy individuals adjusted to the WHO 1 st International Standard ADAMTS13 plasma (NIBSC, Potters Bar, Hert Fordshire, EN6 3QG, UK Official Medicines Control Laboratory, UK).42 For all methods, the lower limit of detection (LLD) was 10 IU/dL and normal range was between $50 \mathrm{lU} / \mathrm{dL}$ and $100 \mathrm{IU} / \mathrm{dL}$. ADAMTS13 activity was also measured using a chromogenic assay providing a LLD of $3 \mathrm{IU} / \mathrm{dL}, 43$ Technozym ADAMTS13 activity ELISA® (ChrVWF73, Technoclone, Vienna, Austria) according to the manufacturer's instructions.

ADAMTS13 autoantibodies were screened using both a home-made functional semi-quantitative assay testing a circulating inhibitor against ADAMTS13 as previously described 20 and an ELISA measuring anti-ADAMTS13 IgG titer using the Technozym ADAMTS13-INH ELISA® assay (Technoclone, Vienna, Austria; positive threshold $>15 \mathrm{IU} / \mathrm{mL}$ ) according to the manufacturer's instructions.22 
ADAMTS13 antigen was measured using 3 assays: the first assay was the commercial IMUBIND ADAMTS13 ELISA $®$ assay (Sekisui Diagnostics, Stamford, CT, USA) used according to the manufacturer's instructions: briefly, ADAMTS13 was captured by a polyclonal anti-ADAMTS13 antibody and stained by a biotinylated polyclonal antibody against ADAMTS13 TSP1-5/TSP1-7 domains; normal range was between $0.63 \mu \mathrm{g} / \mathrm{mL}$ and $0.85 \mu \mathrm{g} / \mathrm{mL}$, and the LLD was $0.065 \mu \mathrm{g} / \mathrm{mL}$, as indicated by the manufacturer. The second assay was a home-made ELISA using a mouse anti-hADAMTS13 capture antibody $3 \mathrm{H} 9$ directed against ADAMTS13 metalloprotease domain and a pool of 2 staining biotinylated mouse anti-hADAMTS13 antibodies $17 \mathrm{G} 2$ and 19H4, as previously described.32,35,44 Normal range determined from 40 healthy donors (normal human plasma, NHP) was between $0.93 \mu \mathrm{g} / \mathrm{mL}$ and 1.35 $\mu \mathrm{g} / \mathrm{mL}$, and the LLD was $0.02 \mu \mathrm{g} / \mathrm{mL} .35$ To further check the presence of ADAMTS13 antigen in patients with detectable ADAMTS13 antigen levels found with the 3H9-based ELISA, we controlled ADAMTS13 antigen levels using a third assay consisting in a home-made ELISA using a mouse anti-hADAMTS13 capture antibody 4B9 directed against ADAMTS13 TSP1-4-5 domains and a pool of 2 staining biotinylated mouse anti-hADAMTS13 antibodies $17 \mathrm{G} 2$ and 19H4, as previously described. 32

\section{ADAMTS13 genetic analysis}

Patients' genomic DNA was screened for sequence variations by direct sequencing of the coding sequence of the ADAMTS13 gene (NM_139025.4) with Big Dye version 3.1, ABI3130XL capillary sequencer (Applied Biosystems, Foster City, CA, USA) and analyzed with SeqScape version 2.5 (Applied Biosystems). We used nomenclature of the Human Genome Variation Society (http://www.hgvs.org/mutnomen/) for the sequence variations. All novel missense mutations and SNPs defined as sequence variations absent from both the dbSNP (built 147), 1000 Genomes, or gnomAD databases were studied in silico using Poly-Phen-2 (http://genetics.bwh.harvard.edu/pph2/), AlignGVD (https://agvgd.iarc.frl), Mutation Taster (http://mutationtaster.org) and SIFT (http://sift-.jcvi.org/) softwares for the prediction on structure and functional effect of protein changes. Ensembl Compara (http://www.ensembl.org/info/genome/compara/index.html) was used for sequence conservation among the species. ADAMTS13 gene mutations were screened using both the international literature (www.pubmed.com) and the databases for ADAMTS13 gene variations (Clinvar: https://www.ncbi.nlm.nuh.gov/clinvar) to determine their deleterious or candidate status. 


\section{ADAMTS13 conformation}

The determination of ADAMTS13 conformation (folded vs open) was performed using a home-made ELISA as previously described.35 Briefly, 96-well microtitrated plates were coated with the antiADAMTS13 spacer domain murine monoclonal antibody 1C4 (capture antibody) which exclusively binds to a cryptic epitope in ADAMTS13 spacer domain when in a so-called open conformation. 35 Only plasma samples which ADAMTS13 antigen level was higher than $0.03 \mu \mathrm{g} / \mathrm{mL}$ with the $3 \mathrm{H} 9$-based ELISA, were added both in the absence $(-17 G 2)$ and in the presence $(+17 G 2)$ of the anti-ADAMTS13 CUB1 domain murine monoclonal antibody 17G2 which induces an open conformation in ADAMTS13, exposing the cryptic epitope of $1 \mathrm{C} 4.30-32$ Finally, bound ADAMTS13 was detected using biotinylated antibody $3 \mathrm{H} 9$ followed by HRP labeled Pierce high sensitivity streptavidin (1/10.000, Invitrogen). Binding of ADAMTS13 to $1 \mathrm{C} 4$ antibody reflected an open conformation of ADAMTS13 with an exposed cryptic epitope in the spacer domain, while no binding of ADAMTS13 to 1C4 reflected a folded conformation of ADAMTS13. In each series, intra-assay controls consisted in both NHP (folded conformation of ADAMTS13) and one patient with acute acquired TTP (previously established with an open conformation of ADAMTS13). The OD490nm values obtained by the 1C4 ELISA were first corrected for ADAMTS13 antigen concentrations and then normalized with the OD490nm value of the intra-assay control (NHP) to express data as a "Conformation index" $(\mathrm{Cl})$. A $\mathrm{Cl}$ above 0.5 defined an open conformation of ADAMTS13 while a Cl below 0.5 defined a folded conformation of ADAMTS13.35

\section{Statistical analysis}

Quantitative parameters were reported as median and interquartile range (IQR, 25th-75th percentile) and qualitative parameters as number and percentage. Graphpad Prism v5.03 software (GraphPad Software Inc., San Diego, CA, USA) was used to analyze statistics (one-way ANOVA). A p-value $<0.05$ was considered as statistically significant.

\section{Results}

\section{Demographic and clinical presentation (inaugural acute phase and follow-up) of USS patients}

Over the 18-year study period, 8421 consecutive patients with either an adult-onset $(n=7309)$ or a child- 
onset ( $n=1112$ ) TMA suspicion were prospectively enrolled in our registry (Fig. 1). Out of adult-onset TTP patients ( $n=1608$ ), 22 patients (from 20 families) were diagnosed with USS and partially previously reported (Fig. 1).22 Of the 1112 patients with child-onset TMA, 87 patients presented with TTP of which 34 cases were identified as USS. Accurate clinical data and plasma samples were available at presentation and during follow-up (median of 11 years [IQR 7; 16]) in the 34 child-onset USS patients from 31 families (Fig. 1) including the 6 princeps French families.9 Demographic and clinical features of this child-onset USS cohort are reported in Table 1: the sex ratio was $1.1 \mathrm{~F} / 1 \mathrm{M}$, comorbidities and familial consanguinity were both identified in about one-third of patients (Table S1). Familial inquiry revealed likely affected members (fetal loss and/or neonatal death of siblings) or affected siblings in $10(31 \%)$ families. Fourteen patients were Caucasian, 14 were Africans (Maghreb, Central Africa, Mauritius, Reunion) or Afro-caribbean (West Indies, Haiti), and 6 were Leibanish, Turkish, Asians (India, Sri Lanka, Pakistan) or had an Asian ancestry (Guyana).

Twenty-six (76\%) patients exhibited symptoms suggestive of TMA immediately at birth (microangiopathic anemia, thrombocytopenia and/or severe icterus), including 14 patients (54\%) who required exchange blood transfusion (Table S2). The first acute TTP episode occurred during the neonatal and the post-neonatal period in 15 patients $(44 \%)$ and during childhood in 17 patients $(50 \%)$. In two patients (6\%) who exhibited TMA symptoms requiring exchange blood transfusion at birth and an unexplained fluctuant thrombocytopenia in childhood, the first TTP episode was reported in adulthood during a first pregnancy (patients 12 and 24, Table S2). During acute TTP episodes, all patients had a microangiopathic hemolytic anemia with schistocytes and a severe thrombocytopenia (platelet count usually $<30 \times 109 / \mathrm{L})$ and 22 of them (65\%) also exhibited one or several visceral ischemia affecting either the kidneys, the brain or the heart (Table S2). A trigger for acute TTP (mainly viral infections and vaccinations) was identified in about two thirds of patients (Table 1). Acute TTP episodes were successfully treated with plasmatherapy in all patients (fresh frozen plasma infusion $10-15 \mathrm{~mL} / \mathrm{kg} / \mathrm{day}$ until remission) (Table S2). During the long-term follow-up (median of 11 years [IQR: 8-16]), no patient died but $7(21 \%)$ patients exhibited more than 10 relapses. TTP sequelae (from renal, neurological and/or cardiac ischemia) were reported in $16(47 \%)$ patients mainly because of initial misdiagnosis (Evans syndrome, immune thrombocytopenic purpura (ITP) and hemolytic uremic syndrome (HUS)). Prophylactic plasmatherapy (10 mL/kg every 2 or 3 weeks) was initiated on the physician's discretion in $28(82 \%)$ patients to prevent relapses and sequelae (Table 1). No patient developed an allo-immune 
response against ADAMTS13.

Adult-onset USS patients were exclusively pregnancy-triggered USS with no TMA symptoms neither at birth, during childhood nor outside of an obstetrical context.20,22 After the diagnosis of USS, all women were actively monitored and successfully treated with prophylactic plasmatherapy throughout subsequent pregnancies and the postpartum period (live birth rate of $100 \%$ ).

\section{Genotypic analysis of ADAMTS13}

In our 34 child-onset USS patients, we identified 5 distinct SNPs (p.Arg7Trp, p.GIn448Glu, p.Ala618Pro, p.Ala732Val and p.Ala900Val) and 43 distinct sequence variations of ADAMTS13 gene different from common SNPs, including $24(56 \%)$ so far unreported sequence variations. These sequence variations were spread all over ADAMTS13 gene without any hot spot (Fig. 2A, Table 2). In most cases, each sequence variation was found in only one family except each of the following 5 sequence variations p.Arg507Glu; p.Ala596Val; p.Glu735*; p.Cys1024Gly and p.Arg1206* - that were found in 2 unrelated families (Table 2). In all patients, at least 2 ADAMTS13 sequence variations were identified, including 3 patients with 3 sequence variations. Fifty-six percent (19/34) of our child-onset USS patients were compound heterozygous for ADAMTS13 sequence variations whereas 44\% (15 patients from 12 families/34 patients) were homozygous for ADAMTS13 mutations. The combination of 2 missense mutations (either $2 \mathrm{~N}$-tem, $2 \mathrm{C}$-term or $1 \mathrm{~N}$-term $+1 \mathrm{C}$-term) was present in $38 \%$ of patients (Fig. $3 \mathrm{~A}$ and $3 \mathrm{~B}$ ).The presence of at least one truncating sequence variation, either associated with another truncating sequence variation $(32 \%)$ or with a missense mutation $(30 \%)$, was the most frequently observed (62\%) (Fig. 3A and 3B).

The genotypic comparison of the current child-onset USS cohort with our adult-onset USS cohort showed some significant differences. Firstly, the panel of ADAMTS13 sequence variations in adult-onset USS was smaller (20 vs 43) and did not overlap with the one of child-onset USS (Fig.2A and 2B). Indeed, there were no shared mutations between both our age onset-dependent sub-cohorts. It also included one hotspot within the TSP1-7 domain consisting in one specific missense mutation, p.Arg1060Trp, found in $82 \%$ (18/22) of patients (15 heterozygous and 3 homozygous) and systematically associated with the p.Ala1033Thr SNP (Table S3). Secondly, the frequency of patients with truncating sequence variations was much lower in adult-onset USS when compared to child-onset USS ( $36 \%$ vs $62 \%$ ) (Fig. $3 \mathrm{~A})$, especially when considering the association of 2 truncating sequence variations ( $5 \%$ vs $32 \%$ ). 
Thirdly, in contrast to all child-onset USS patients whose both ADAMTS13 alleles were affected with deleterious sequence variations, 2 adult-onset USS patients $(9 \%, 2 / 22)$ were found with only one ADAMTS13 missense mutation (p.Arg1060Trp) combined with several SNP (Fig. 3A and 3B, patients A02 and A20 from Table 4) i.e. p.Arg7Trp, p.GIn448Glu, p.Pro618Ala, p.Ala732Val and p.Ala1033Thr (Table 4 and Table S3). Fourthly, the rate of homozygous patients was much lower in adult-onset USS when compared to child-onset USS (18\%, $4 / 22$ vs $44 \%, 15 / 34)$ (data not shown).

\section{Phenotypic ADAMTS13 characterization}

ADAMTS13 antigen levels were found undetectable with the commercial assay ( $<0.065 \mu \mathrm{g} / \mathrm{mL} L L D)$ in all child-onset USS patients (Table S1) but detectable although very low (between $0.050 \mu \mathrm{g} / \mathrm{mL}$ and $0.068 \mu \mathrm{g} / \mathrm{mL}$ ) using the $3 \mathrm{H} 9$-based ELISA in 5 child-onset USS patients (5/33 samples tested, $15 \%$ ) (Fig.4A, Table S1). All patients had a persistent and severe ADAMTS13 deficiency in plasma with all home-made reference methods (ADAMTS13 activity $<10 \mathrm{IU} / \mathrm{dL}$ ) and also with the Chr-VWF73 assay (ADAMTS13 activity <3 IU/dL) (Fig. 4B). No patient had a detectable inhibitor against ADAMTS13 or anti-ADAMTS13 IgG during the acute phase and the follow-up.

In adult-onset USS patients, the proportion of ADAMTS13 antigen higher than $0.03 \mu \mathrm{g} / \mathrm{mL}$ (using the 3H9-based ELISA) was much higher when compared to pediatric patients $(p<0.005)$ as 11 adult patients (11/20 samples tested, $55 \%$ ) had detectable although very low ADAMTS13 antigen levels (ranging from $0.034 \mu \mathrm{g} / \mathrm{mL}$ to $0.201 \mu \mathrm{g} / \mathrm{mL}$ ) (Fig. 4A, Table 4). Interestingly, ADAMTS13 activity (Chr-VWF73 assay) was measurable (between 3 and $10 \mathrm{IU} / \mathrm{dL}$ ) in 10 adult-onset USS patients (10/17 samples tested, 59\%) (Fig. 4B). Also, patients A02, A14 and A20 (Table 4) recovered a detectable ADAMTS13 activity ranging from 12 to $20 \mathrm{IU} / \mathrm{dL}$ in remission phase studied several years after the inaugural pregnancy-induced acute TTP episode.

\section{ADAMTS13 folded/open conformation}

Finally, 16 USS patients ( 5 child-onset and 11 adult-onset) exhibited ADAMTS13 antigen levels above $0.030 \mu \mathrm{g} / \mathrm{mL}$ allowing the study of ADAMTS13 conformation (Table 4). In healthy individuals, ADAMTS13 conformation is folded under normal conditions and changes to an open conformation when antibody $17 \mathrm{G} 2$ is added.35 Interestingly, native ADAMTS13 conformation (without addition of 17G2 antibody) exhibited variable profiles in child-onset USS patients (Fig. 4C): 3 patients had a folded 
ADAMTS13 (children 08, 10 and 33, Table 4) while 2 patients had an abnormally open ADAMTS13 (children 13 and 30, Table 4). After addition of $17 \mathrm{G} 2$ antibody, ADAMTS13 remained folded in the 3 patients whose native ADAMTS13 was folded. Surprisingly, in one patient whose native ADAMTS13 was open, ADAMTS13 folded again after addition of $17 \mathrm{G} 2$ (child 30, Table 4). In the other patient with an open ADAMTS13, ADAMTS13 remained open after addition of 17G2 (child 13, Table 4).

In contrast to the child-onset USS patients, ADAMTS13 was folded in all 11 adult-onset USS (Fig. 4D). However, when adding 17G2 antibody, ADAMTS13 remained folded in 9 patients with bi-allelic mutations of ADAMTS13 gene (adults $01,03,04,08,10,11,14,15,19$, Table 4) but opened in 2 patients with one heterozygous mutation of ADAMTS13 gene associated with several SNPs (adults 02 and 20, Table 4) (Fig.4D).

\section{Correlation between ADAMTS13 genotype, USS clinical/biological phenotype and ADAMTS13 conformation}

In our child-onset USS patients, no obvious correlation was found between the clinical features (ageonset of the first TTP episode, presence of visceral ischemia, relapses, ischemic sequelae, prophylactic plasmatherapy and delay between 2 FFP infusions), the biological phenotype (ADAMTS13 antigen using the 3H9-based ELISA, ADAMTS13 conformation) and the genotype (features of ADAMTS13 sequence variations i.e. localization within $\mathrm{N}$-terminal part versus $\mathrm{C}$-terminal part domains and missense versus truncating mutations) (Suppl. Fig.1). Whatever their genotype, ADAMTS13 activity was lower than $3 \mathrm{IU} / \mathrm{dL}$ in all pediatric patients. Correlation between ADAMTS13 genotype and ADAMTS13 conformation was difficult to establish considering the small number of tested patients. However, interestingly, all 5 patients exhibited abnormal ADAMTS13 conformation profile when compared to NHP and all of them had ADAMTS13 sequence variations affecting some domains of ADAMTS13 (spacer, TSP1-5, TSP1-7, CUB1, CUB2) that may interfere either with the physiologic inhibitory CUB-spacer interaction defining ADAMTS13 native conformation or with the access of 17G2 antibody to ADAMTS13 CUB1 domain (Fig. 4C, Table 4). In that regard, the most paradoxical abnormality of ADAMTS13 conformation (open in native state and closed after addition of 17G2 antibody) was interestingly observed in the one patient who exhibited a homozygous mutation of ADAMTS13 CUB1 domain (p.Arg1206*) (Fig. 4C). 
In contrast to child-onset USS, adult-onset USS showed a better correlation between clinical features and ADAMTS13 genotype considering the homogeneity of both clinical presentation (pregnancy-onset TTP) and genetics (hotspot of p.Arg1060Trp mutation). However, the N-terminal/C-terminal localization and the missense/truncating feature of ADAMTS13 sequence variation did not significantly influence ADAMTS13 antigen levels (Suppl. Fig.1). Also, the miscellaneous ADAMTS13 sequence variations did not influence ADAMTS13 native conformation, found similar to that of NHP (Fig.4D).

\section{Discussion}

Our study provides a global picture of USS in France with 56 patients from 51 families (prevalence $\sim 0.86$ cases/million on June 1,2017$)$ exhibiting 63 distinct sequence variations of ADAMTS13 gene. Comparing children and adult patients, we show that the age-onset of USS defines two distinct entities and that ADAMTS13 sequence variations have an impact on ADAMTS13 conformation.

The clinical and biological features of our USS cohort are globally in line with those reported in the international literature encompassing $~ 200$ USS patients worldwide with $\sim 180$ distinct sequence variations of ADAMTS13 gene.17,27,45,46 Child-onset and adult-onset USS are totally distinct entities, especially in terms of clinical presentation and prophylactic treatment requirement. Our child-onset USS patients exhibited a severe disease characterized by a $47 \%$ rate of ischemic sequelae and a high frequency of relapses requiring efficient prophylactic plasma therapy in $82 \%$ of cases. In contrast, our adult-onset USS patients were exclusively pregnancy-induced TTP with no relapse and no requirement for plasma prophylaxis out of an obstetrical context. Although mean ADAMTS13 antigen levels were significantly lower in children when compared to adults, they were not correlated with the features of ADAMTS13 sequence variations. Therefore, the age-onset dependent clinical presentation of USS is likely to be directly related to the penetrance spectrum of ADAMTS13 sequence variations which shows no overlap between children and adult patients. These results are contrasting with some previous studies performed in smaller series of USS patients where a correlation between ADAMTS13 mutations and ADAMTS13 antigen levels was suggested.11,12 Interestingly, none of our USS patients died during the short- and long-term follow-up. However, the mortality rate could be underestimated because 8 families reported fetal loss, intrauterine fetal or neonatal death in siblings whose DNA was not available for further investigations (data not shown). 
The majority of our USS patients ( 65\%) are compound heterozygous for ADAMTS13 sequence variations, making it difficult to establish strong phenotype/genotype correlations. Moreover, additional factors like SNPs may play a role in the phenotype variability.47 About half of the mutations reported in the current study were previously described.8-15 Two sequence variations observed in European patients deserve specific attention: firstly, the c.4143_4144dupA resulting in a frameshift in exon 29 and exclusively reported in patients with an ancestry from central and northern Europes,13,48 was found in $4.4 \%$ of the alleles of our child-onset USS patients whose familial inquiry interestingly identified ancestries from central Europe; secondly, the c.3178C >T mutation (p.Arg1060Trp) in exon 24 leading to a severely impaired ADAMTS13 synthesis and secretion 18,49 and reported with a high prevalence in patients from Europe, Scandinavia, North America and Turkey 15 was present in $48 \%$ of the alleles of our adult-onset USS patients. Moreover, as previously reported by Camilleri and collaborators, 18 two patients from our cohort with an adult-onset USS acute presentation exhibited only one identified mutation, the heterozygous p.Arg1060Trp, associated with a cluster of ADAMTS13 SNPs; interestingly, they recovered a very moderate ADAMTS13 activity (fluctuating between 12 and $20 \mathrm{IU} / \mathrm{dL}$ ) in remission. As expected, the overlap between ADAMTS13 sequence variations found in our patients and Japanese patients46 is weak but two ADAMTS13 sequence variations published in the Japanese Registry 10 were however found in two of our families with Asian ancestry, one from Guyana (p.Arg268Pro) and one from Sri Lanka (p.Arg1206*). Also, in contrast to the Japanese USS cohort46 and to the worldwide USS patients carrying the c.4143_4144dupA,8,13,48 the dichotomy of USS age onset looks very strict in French USS patients as there were no shared mutations between the child-onset and the adult-onset subcohorts.

In addition to this clinical and biological study of the French patients with USS, we decided to investigate the influence of the ADAMTS13 sequence variations on the ADAMTS13 conformation using a very recently developed ELISA.35 Using this new tool, an open conformation of ADAMTS13 was shown to be a hallmark of acute autoimmune TTP. .35 Because ADAMTS13 autoantibodies developed in patients with autoimmune TTP are polyclonal,3,6,50 they may interfere with the physiologic binding of the N-term Metalloprotease/Disintegrin/Thrombospondin1-1/Cystein-rich/Spacer (MDTCS) domains to the C-term CUB domains that normally maintains the closed native ADAMTS13 conformation. As a complementary approach, studying the influence of USS-related ADAMTS13 sequence variations on ADAMTS13 conformation may bring new insights in the structure related-mechanisms that govern the auto- 
interaction of ADAMTS13 domains. The current study shows that ADAMTS13 adopts several profiles of conformation in USS.

Overall, patients considered as cross reactive material positive $(\mathrm{CRM}+)$ cases for ADAMTS13 represented $\sim 29 \%(16 / 56)$ of our USS cohort and thus, could be tested for ADAMTS13 conformation. The native conformation of ADAMTS13 was not modified by ADAMTS13 sequence variations in 14/16 USS patients (Fig. 4C and 4D; Table 4). In other terms, their combinations of sequence variations involving the TSP1-7 domain in 12 patients (p.Arg1060Trp and p.Cys1067Serfs*30), the CUB2 domain in one patient (c.988-2A>G/p.Asp1362Val) and the spacer domain (p.Ala596Val) in another patient, did not alter the auto-inhibitory spacer-CUB interaction. Among those mutations, only mutations p.Ala596Val and p.Arg1060Trp were present at the homozygous state and then, may be concluded with no consequence on ADAMTS13 native conformation. In contrast, 2 patients (with c.13091G>A/p.Cys908Ser and p.Arg1206*/p.Arg1206* genotype, respectively) / 16 exhibited an abnormally open ADAMTS13 native conformation (Fig.4C). These results show that the Cys908 residue (TSP1-5 domain) may play a role in the looped organization of the TSP1-2 to 7 domains enabling the proximity between the $\mathrm{N}$ - and $\mathrm{C}$-terminal regions of native ADAMTS13. Also, the Arg1206 residue itself or the following residues of CUB1-CUB2 domains may be important for the auto-inhibitory binding of the CUB1 domain to the spacer domain.33

The switch of ADAMTS13 conformation expected after addition of $17 G 2$ antibody was disturbed in 13/16 patients. In 12 patients, ADAMTS13 remained folded suggesting that their ADAMTS13 sequence variations interfere with the conformational activation induced by $17 G 2$ antibody. In one unique patient with p.Arg1206*/p.Arg1206* genotype, it seems that ADAMTS13 paradoxically switched from open to folded (Fig. 4B and 4C, Table 4). We hypothesize that the truncating mutation p.Arg1206* (truncating a big part of the CUB1 domain) interrupts the spacer-CUB interaction leading to an open ADAMTS13. In addition, ADAMTS13 of this specific patient has a closed conformation in the presence of the 17G2 antibody. Whether 17G2 antibody really closes the conformation of ADAMTS13 or whether the $p$. Arg1206* modifies the epitope of the 17G2 antibody (anti-CUB1) and hence interferes with the ELISA, remains to be determined. Studies with recombinant ADAMTS13 variants are currently ongoing to study the effect of the different mutations on ADAMTS13 conformation and allosteric activation. AntiADAMTS13 antibodies are usually screened and titrated in patients benefitting from regular prophylactic 
plasma therapy. However, no case of alloimmunization against ADAMTS13 after plasma therapy has been reported yet.

This study has some strength i.e. the large number and the long-term follow-up of patients, the presentation of both pediatric and adult patients and the innovative data about ADAMTS 13 conformation but it also has some limitations: firstly, we cannot guarantee a perfect exhaustiveness of enrollment in spite of an efficient national organization for rare diseases; secondly, we did not express mutated recombinant ADAMTS13 to prove in vitro the deleterious effect of the 63 ADAMTS13 sequence variations found in our patients; thirdly, the study of ADAMTS13 conformation is of limited benefit for patients because a quantitative deficiency of plasma ADAMTS13 is the predominant mechanism for their functional ADAMTS13 defect.

In conclusion, USS is a rare entity within a rare disease, characterized by a great molecular heterogeneity limiting the phenotype/genotype correlation. Further studies should be performed to characterize the effect of ADAMTS13 gene variations on ADAMTS13 conformation. While curative and prophylactic plasmatherapy is the only available and efficient therapy in USS today, the innovating recombinant ADAMTS13 appears very promising and should help to both improve clinical management and establish therapeutic guidelines..$^{14,51,52}$

\section{Authors' Contributions}

Contribution: B.S.J. collected, analyzed, interpreted data, and wrote the manuscript; A.V. and P.C. designed and supervised the study and co-wrote the manuscript; B.S.J. and E.R. performed and interpreted ADAMTS13 phenotypic experiments; P.B. and C.G. performed genetic analysis and critically reviewed the manuscript; K.V. designed and supervised research, interpreted data and reviewed the manuscript for scientific content; NB, JH, FP and YD included patients; AS, NB, JH, FP and YD coanalyzed data and critically reviewed the manuscript. The final version of the manuscript was read and approved by all authors.

\section{Funding}

This work was partly funded by a grant from the Délégation Régionale à la Recherche Clinique, Assistance Publique-Hôpitaux de Paris (PHRC AOM05012) and declared at ClinicalTrials.gov record 
(http://clinicaltrials.gov/show/NCT00426686, study ID number: P051064, Health Authority: France, Ministry of Health), a grant from CSL-Behring (AP-HP-2017-47-26) and a grant from Fondation d'entreprise Groupe Pasteur Mutualité. This study was also supported by the National Plan for Rare Diseases of the French Ministry of Health and the European Framework Program for Research and Innovation (HORIZON 2020 Marie Sklodowska-Curie Innovative training network PROFILE grant 675746).

\section{Acknowledgments}

We thank An-Sofie Schelpe for kindly providing anti-ADAMTS13 antibodies and for her expertise.

We also thank Sandrine Thouzeau-Benghezal, Sophie Capdenat, Paulette Legendre, Sandrine Malot, Sylvaine Savigny, Isabelle Turquois, Nele Vandeputte and Aline Vandenbulcke for expert assistance.

Conflict-of-interest disclosure: B.S.J. received the MaRIH award from Alexion. P.C. is a member of the Advisory boards for Ablynx, Alexion, Octapharma and Cerus. A.V. and K.V. are members of the Advisory board for Ablynx. All other authors declare no competing financial interests.

\section{Supporting information}

Additional Supporting Information may be found on the online version of this article.

Table S1. Demographic data and ADAMTS13 phenotype investigations in 34 patients (31 families) with child-onset Upschaw-Schulman syndrome.

Table S2. Clinical features of 34 patients with child-onset Upschaw-Schulman syndrome.

Table S3. Genetic analysis of ADAMTS13 gene polymorphisms in 56 patients with Upschaw-Schulman syndrome.

Figure S1. Correlation between ADAMTS13 genotype and ADAMTS13 antigen in 53/56 patients with Upshaw-Schulman syndrome (USS). 


\section{Appendix :}

The members of the Reference Center for Thrombotic Microangiopathies (CNR-MAT) are: Augusto Jean-François (Service de Néphrologie, dialyse et transplantation ; CHU Larrey, Angers); Azoulay Elie (Service de Réanimation Médicale, Hôpital Saint-Louis, Paris); Barbay Virginie (Laboratoire d'Hématologie, CHU Charles Nicolle, Rouen); Benhamou Ygal (Service de Médecine Interne, CHU Charles Nicolle, Rouen); Bordessoule Dominique (Service d'Hématologie, Hôpital Dupuytren, Limoges); Boyer Olivia (Service de Néphrologie Pédiatrique, Hôpital Necker) ; Charasse Christophe (Service de Néphrologie, Centre Hospitalier de Saint-Brieuc); Charvet-Rumpler Anne (Service d'Hématologie, CHU de Dijon) ; Chauveau Dominique (Service de Néphrologie et Immunologie Clinique, CHU Rangueil, Toulouse); Choukroun Gabriel (Service de Néphrologie, Hôpital Sud, Amiens); Coindre Jean-Philippe (Service de Néphrologie, CH Le Mans); Coppo Paul (Service d'Hématologie, Hôpital Saint-Antoine, Paris); Corre Elise (Service d'Hématologie, Hôpital Saint-Antoine, Paris); Delmas Yahsou (Service de Néphrologie, Hôpital Pellegrin, Bordeaux); Deschenes Georges (Service de Néphrologie Pédiatrique, Hôpital Robert Debré, Paris); Devidas Alain (Service d'Hématologie, Hôpital Sud-Francilien, CorbeilEssonnes); Dossier Antoine (Service de Néphrologie, Hôpital Bichat, Paris); Dossier Claire (Service de Néphrologie Pédiatrique, Hôpital Robert Debré, Paris); Fain Olivier (Service de Médecine Interne, Hôpital Saint-Antoine, Paris); Fakhouri Fadi (Service de Néphrologie, CHU Hôtel-Dieu, Nantes) ; Frémeaux-Bacchi Véronique (Laboratoire d'Immunologie, Hôpital Européen Georges Pompidou, Paris); Galicier Lionel (Service d'Immunopathologie, Hôpital Saint-Louis, Paris); Grangé Steven (Service de Réanimation Médicale, CHU Charles Nicolle, Rouen) ; Guidet Bertrand (Service de Réanimation Médicale, Hôpital Saint-Antoine, Paris); Halimi Jean-Michel (Service de Néphrologie Pédiatrique, Hôpital Bretonneau, Tours); Hamidou Mohamed (Service de Médecine Interne, Hôtel-Dieu, Nantes); Herbrecht Raoul (service d'Oncologie et d'Hématologie, Hôpital de Hautepierre, Strasbourg); Hié Miguel (Service de Médecine Interne, Groupe Hospitalier Pitié-Salpétrière, Paris) ; Jacobs Frédéric (Service de Réanimation Médicale, Hôpital Antoine Béclère, Clamart); Joly Bérangère (Service d'Hématologie Biologique, Hôpital Lariboisière, Paris) ; Kanouni Tarik (Unité d'Hémaphrèse, Service d'Hématologie, CHU de Montpellier) ; Kaplanski Gilles (Service de Médecine Interne, Hôpital la Conception, Marseille) ; Lautrette Alexandre (Service de Néphrologie Pédiatrique B, Hôpital Hôtel-Dieu, Clermont-Ferrand); Le Guern Véronique (Unité d'Hémaphérèse, Service de Médecine Interne, Hôpital Cochin, Paris) ; Lequintrec Moglie (Service de Néphrologie, CHU de Montpellier) ; Loirat Chantal (Service de Néphrologie Pédiatrique, Hôpital Robert Debré, Paris); Moulin Bruno (Service de Néphrologie, Hôpital Civil, Strasbourg); Mousson Christiane (Service de Néphrologie, CHU de Dijon); Ojeda Uribe Mario (Service d'Hématologie, Hôpital Emile Muller, Mulhouse); Ouchenir Abdelkader (Service de Réanimation, Hôpital Louis Pasteur, Le Coudray); Parquet Nathalie (Unité de Clinique Transfusionnelle, Hôpital Cochin, Paris); Peltier Julie (Urgences Néphrologiques et Transplantation Rénale, Hôpital Tenon, Paris) ; Pène Frédéric (Service de Réanimation Médicale, Hôpital Cochin, Paris) ; Perez Pierre (Service de Réanimation polyvalente, CHU de Nancy) ; Poullin Pascale (Service d'hémaphérèse et d'autotransfusion, Hôpital la Conception, Marseille); Pouteil-Noble Claire (Service de Néphrologie, CHU Lyon-Sud, Lyon); Presne Claire (Service de Néphrologie, Hôpital Nord, Amiens); Provôt François (Service de Néphrologie, Hôpital Albert Calmette, Lille); Rondeau Eric (Urgences Néphrologiques et Transplantation Rénale, Hôpital Tenon, Paris); Saheb Samir (Unité d'Hémaphérèse, Hôpital la PitiéSalpétrière, Paris) ; Schlemmer Benoît (Service de Réanimation Médicale, Hôpital Saint-Louis, Paris); Seguin Amélie (Service de Réanimation Médicale, centre hospitalier de Vendée) ; Servais Aude (Service de Néphrologie, CHU Necker-Enfants Malades); Stépanian Alain (Laboratoire d'Hématologie, Hôpital Lariboisière, Paris); Vernant Jean-Paul (Service d'Hématologie, Hôpital la Pitié-Salpétrière, Paris); Veyradier Agnès (Service d'Hématologie Biologique, Hôpital Lariboisière, Paris); Vigneau Cécile (Service de Néphrologie, Hôpital Pontchaillou, Rennes); Wynckel Alain (Service de Néphrologie, Hôpital Maison Blanche, Reims); Zuber Julien (Service de Néphrologie, CHU Necker-Enfants Malades); Zunic Patricia (Service d'Hématologie, Groupe Hospitalier Sud-Réunion, la Réunion).

The collaborators who included patients for this specific study are: Bakiri Faouzi (Service d'Hématologie, Hôpital Felix Guyon, Saint Denis de la Réunion); Benhamou Ygal (Service de Médecine Interne, CHU Charles Nicolle, Rouen); Berger Claire (Service de Pédiatrie, CHU Saint Etienne, Saint Etienne); Bonnotte Bernard (Service de Médecine interne, Hôpital du Bocage, Dijon); Borgi Aida (Service de Pédiatrie, Hôpital de Tunis, Tunisie); Buffin Arnaud (Service de Pédiatrie, CH de Chambéry); Chauveau Dominique (Service de Néphrologie, Hôpital Rangueil, Toulouse); Choukroun Gabriel (Service de Néphrologie, CHU d'Amiens); Delattre Pierre (Service de Pédiatrie, $\mathrm{CH}$ de Cayenne, Guyane); Deschênes Georges (Service de Néphrologie pédiatrique, Hôpital Robert Debré, APHP, Paris); Dunogue Bertrand (Service de Médecine interne, Hôpital Cochin, Paris); Gobert Pierre (Service de Médecine Interne-Néphrologie, CHU d'Avignon); Groza Monica (Service de Médecine Interne, Hôpitaux civils de Colmar); Halimi Jean-Michel (Service de Néphrologie Pédiatrique, Hôpital Clocheville, 
CHU de Tours); Herbrecht Raoul (Service d'Oncologie et Hématologie, Hôpital de Hautepierre, CHU de Strasbourg); Hie Miguel (Service de Médecine Interne, Hôpital Pitié Salpêtrière, Paris); Hot Arnaud (Service de Médecine Interne, Hôpital Edouard Herriot, Lyon); Kieffer Pierre (Service de Médecine Interne, Hôpital Emile Muller, Mulhouse); Lakhdari Mustapha (Service de Pédiatrie, CH de Gonesse); Legallicier Bruno (Service de Néphrologie, CHU Charles Nicolle, Rouen); Mansuy Ludovic (Service de Pédiatrie, CHU de Nancy); Nivet Hubert (Service de Néphrologie Pédiatrique, CHU de Tours); Nurden Paquita (Service d'Hématologie, Hôpital Pellegrin, CHU de Bordeaux); Ojeda-Uribe Mario (Service d'Hématologie clinique, Hôpital Emile Muller, Mulhouse); Puneet Jain (Department of Pediatrics, AlIMS, New Delhi, India); Ranta Dana (Service d'Hématologie, CHU de Nancy); Touahri Tahar (Service d'Hématologie, Hôpital Felix Guyon, Saint-Denis de la Réunion); Thouret Marie-Christine (Service de Pédiatrie, Hôpital de l'Archet, Nice); Ulinski Tim (Service de Néphrologie Pédiatrique, Hôpital Trousseau, APHP, Paris); Vannier Jean-Pierre (Service d'Hématologie et Oncologie Pédiatrique, CHU Charles Nicolle, Rouen); Wynckel Alain (Service de Néphrologie, Hôpital Maison Blanche, Reims). 


\section{References}

1. Zheng XL. ADAMTS13 and von Willebrand factor in thrombotic thrombocytopenic purpura. Annu Rev Med 2015;66:211-225.

2. Kremer Hovinga JA, Coppo P, Lämmle B, et al. Thrombotic thrombocytopenic purpura. Nat Rev Dis Primer 2017;3:17020.

3. Sadler JE. Pathophysiology of thrombotic thrombocytopenic purpura. Blood 2017;130(10):1181 1188.

4. Furlan M, Robles R, Galbusera M, et al. von Willebrand factor-cleaving protease in thrombotic thrombocytopenic purpura and the hemolytic-uremic syndrome. N Engl J Med 1998;339(22):1578 -1584 .

5. Tsai HM, Lian EC. Antibodies to von Willebrand factor-cleaving protease in acute thrombotic thrombocytopenic purpura. N Engl J Med 1998;339(22):1585-1594.

6. Joly BS, Coppo P, Veyradier A. Thrombotic thrombocytopenic purpura. Blood 2017;129(21):2836 -2846 .

7. Levy GG, Nichols WC, Lian EC, et al. Mutations in a member of the ADAMTS gene family cause thrombotic thrombocytopenic purpura. Nature 2001;413(6855):488-494.

8. Schneppenheim R, Budde $U$, Oyen $F$, et al. von Willebrand factor cleaving protease and ADAMTS13 mutations in childhood TTP. Blood 2003;101(5):1845-1850.

9. Veyradier A, Lavergne J-M, Ribba A-S, et al. Ten candidate ADAMTS13 mutations in six French families with congenital thrombotic thrombocytopenic purpura (Upshaw-Schulman syndrome). J Thromb Haemost 2004;2(3):424-429.

10. Fujimura $Y$, Matsumoto $M$, Isonishi A, et al. Natural history of Upshaw-Schulman syndrome based on ADAMTS13 gene analysis in Japan. J Thromb Haemost 2011;9 Suppl 1:283-301.

11. Camilleri RS, Scully M, Thomas $M$, et al. A phenotype-genotype correlation of ADAMTS13 mutations in congenital thrombotic thrombocytopenic purpura patients treated in the United Kingdom. J Thromb Haemost 2012;10(9):1792-1801.

12. Lotta LA, Wu HM, Mackie IJ, et al. Residual plasmatic activity of ADAMTS13 is correlated with phenotype severity in congenital thrombotic thrombocytopenic purpura. Blood 2012;120(2):440448.

13. Mansouri Taleghani M, von Krogh A-S, Fujimura $Y$, et al. Hereditary thrombotic thrombocytopenic purpura and the hereditary TTP registry. Hämostaseologie 2013;33(2):138-143.

14. Scully $\mathrm{M}$, Thomas $\mathrm{M}$, Underwood $\mathrm{M}$, et al. Thrombotic thrombocytopenic purpura and pregnancy: presentation, management, and subsequent pregnancy outcomes. Blood 2014;124(2):211-219.

15. von Krogh AS, Quist-Paulsen P, Waage A, et al. High prevalence of hereditary thrombotic thrombocytopenic purpura in central Norway: from clinical observation to evidence. J Thromb Haemost 2016;14(1):73-82.

16. Joly BS, Stepanian A, Leblanc T, et al. Child-onset and adolescent-onset acquired thrombotic thrombocytopenic purpura with severe ADAMTS13 deficiency: a cohort study of the French national registry for thrombotic microangiopathy. Lancet Haematol 2016;3(11):e537-46. 
17. Fujimura $\mathrm{Y}$, Matsumoto $\mathrm{M}$, Yagi $\mathrm{H}$, et al. Von Willebrand factor-cleaving protease and UpshawSchulman syndrome. Int J Hematol 2002;75(1):25-34.

18. Camilleri RS, Cohen H, Mackie IJ, et al. Prevalence of the ADAMTS-13 missense mutation R1060W in late onset adult thrombotic thrombocytopenic purpura. J Thromb Haemost 2008;6(2):331-338.

19. Fujimura $Y$, Matsumoto M, Kokame K, et al. Pregnancy-induced thrombocytopenia and TTP, and the risk of fetal death, in Upshaw-Schulman syndrome: a series of 15 pregnancies in 9 genotyped patients. Br J Haematol 2009;144(5):742-754.

20. Moatti-Cohen M, Garrec C, Wolf M, et al. Unexpected frequency of Upshaw-Schulman syndrome in pregnancy-onset thrombotic thrombocytopenic purpura. Blood 2012;119(24):5888-5897.

21. von Krogh A-S, Kremer Hovinga JA, Tjønnfjord GE, et al. The impact of congenital thrombotic thrombocytopenic purpura on pregnancy complications. Thromb Haemost 2014;111(6):11801183.

22. Mariotte E, Azoulay E, Galicier L, et al. Epidemiology and pathophysiology of adulthood-onset thrombotic microangiopathy with severe ADAMTS13 deficiency (thrombotic thrombocytopenic purpura): a cross-sectional analysis of the French national registry for thrombotic microangiopathy. Lancet Haematol 2016;3(5):e237-245.

23. Kokame K, Matsumoto M, Soejima K, et al. Mutations and common polymorphisms in ADAMTS13 gene responsible for von Willebrand factor-cleaving protease activity. Proc Natl Acad Sci USA 2002;99(18):11902-11907.

24. Matsumoto M, Kokame K, Soejima K, et al. Molecular characterization of ADAMTS13 gene mutations in Japanese patients with Upshaw-Schulman syndrome. Blood 2004;103(4):13051310.

25. Donadelli R, Banterla F, Galbusera M, et al. In-vitro and in-vivo consequences of mutations in the von Willebrand factor cleaving protease ADAMTS13 in thrombotic thrombocytopenic purpura. Thromb Haemost 2006;96(4):454-464.

26. Hommais A, Rayes J, Houllier A, et al. Molecular characterization of four ADAMTS13 mutations responsible for congenital thrombotic thrombocytopenic purpura (Upshaw-Schulman syndrome). Thromb Haemost 2007;98(3):593-599.

27. Lotta LA, Garagiola I, Palla R, et al. ADAMTS13 mutations and polymorphisms in congenital thrombotic thrombocytopenic purpura. Hum Mutat 2010;31(1):11-19.

28. Hing ZA, Schiller T, Wu A, et al. Multiple in silico tools predict phenotypic manifestations in congenital thrombotic thrombocytopenic purpura. Br J Haematol 2013;160(6):825-837.

29. Tao Z, Peng Y, Nolasco L, et al. Recombinant CUB-1 domain polypeptide inhibits the cleavage of ULVWF strings by ADAMTS13 under flow conditions. Blood 2005;106(13):4139-4145.

30. Muia J, Zhu J, Gupta G, et al. Allosteric activation of ADAMTS13 by von Willebrand factor. Proc Natl Acad Sci USA 2014;111(52):18584-18589.

31. South K, Luken BM, Crawley JTB, et al. Conformational activation of ADAMTS13. Proc Natl Acad Sci USA 2014;111(52):18578-18583.

32. Deforche L, Roose E, Vandenbulcke A, et al. Linker regions and flexibility around the metalloprotease domain account for conformational activation of ADAMTS-13. J Thromb Haemost 2015;13(11):2063-2075. 
33. South K, Lane DA. ADAMTS-13 and von Willebrand factor: a dynamic duo. J Thromb Haemost 2018;16(1):6-18.

34. Feys HB, Anderson PJ, Vanhoorelbeke $K$, et al. Multi-step binding of ADAMTS-13 to von Willebrand factor. J Thromb Haemost 2009;7(12):2088-2095.

35. Roose E, Schelpe AS, Joly BS, et al. An open conformation of ADAMTS13 is a hallmark of acute acquired thrombotic thrombocytopenic purpura. J Thromb Haemost 2018;16(2):378-388.

36. Coppo P, Schwarzinger M, Buffet $M$, et al. Predictive features of severe acquired ADAMTS13 deficiency in idiopathic thrombotic microangiopathies: the French TMA reference center experience. PloS One 2010;5(4):e10208.

37. Scully $\mathrm{M}$, Cataland $\mathrm{S}$, Coppo $\mathrm{P}$, et al. Consensus on the standardization of terminology in thrombotic thrombocytopenic purpura and related thrombotic microangiopathies. J Thromb Haemost 2017;15(2):312-322.

38. Veyradier A, Obert B, Houllier A, et al. Specific von Willebrand factor-cleaving protease in thrombotic microangiopathies: a study of 111 cases. Blood 2001;98(6):1765-1772.

39. Kokame K, Nobe Y, Kokubo Y, et al. FRETS-VWF73, a first fluorogenic substrate for ADAMTS13 assay. Br J Haematol 2005;129(1):93-100.

40. Obert $\mathrm{B}$, Tout $\mathrm{H}$, Veyradier $\mathrm{A}$, et al. Estimation of the von Willebrand factor-cleaving protease in plasma using monoclonal antibodies to vWF. Thromb Haemost 1999;82(5):1382-1385.

41. Gerritsen HE, Turecek PL, Schwarz HP, et al. Assay of von Willebrand factor (vWF)-cleaving protease based on decreased collagen binding affinity of degraded VWF: a tool for the diagnosis of thrombotic thrombocytopenic purpura (TTP). Thromb Haemost 1999;82(5):1386-1389.

42. Hubbard AR, Heath $A B$, Kremer Hovinga JA, Subcommittee on von Willebrand Factor. Establishment of the WHO 1st International Standard ADAMTS13, plasma (12/252): communication from the SSC of the ISTH. J Thromb Haemost 2015;13(6):1151-1153.

43. Joly B, Stepanian A, Hajage D, et al. Evaluation of a chromogenic commercial assay using VWF73 peptide for ADAMTS13 activity measurement. Thromb Res 2014;134(5):1074-1080.

44. Feys HB, Roodt J, Vandeputte N, et al. Thrombotic thrombocytopenic purpura directly linked with ADAMTS13 inhibition in the baboon (Papio ursinus). Blood 2010;116(12):2005-2010.

45. Hovinga JAK, Vesely SK, Terrell DR, et al. Survival and relapse in patients with thrombotic thrombocytopenic purpura. Blood 2010;115(8):1500-1511.

46. Miyata $\mathrm{T}$, Kokame $\mathrm{K}$, Matsumoto $\mathrm{M}$, et al. ADAMTS13 activity and genetic mutations in Japan. Hamostaseologie 2013;33(2):131-137.

47. Plaimauer B, Fuhrmann J, Mohr G, et al. Modulation of ADAMTS13 secretion and specific activity by a combination of common amino acid polymorphisms and a missense mutation. Blood 2006;107(1):118-125.

48. Schneppenheim R, Kremer Hovinga JA, Becker T, et al. A common origin of the 4143insA ADAMTS13 mutation. Thromb Haemost 2006;96(1):3-6.

49. Tao Z, Anthony K, Peng Y, et al. Novel ADAMTS-13 mutations in an adult with delayed onset thrombotic thrombocytopenic purpura. J Thromb Haemost 2006;4(9):1931-1935. 
50. Casina VC, Hu W, Mao J-H, et al. High-resolution epitope mapping by $\mathrm{HX}$ MS reveals the pathogenic mechanism and a possible therapy for autoimmune TTP syndrome. Proc Natl Acad Sci USA 2015;112(31):9620-9625.

51. Tersteeg C, Schiviz A, De Meyer SF, et al. Potential for Recombinant ADAMTS13 as an Effective Therapy for Acquired Thrombotic Thrombocytopenic Purpura. Arterioscler Thromb Vasc Biol 2015;35(11):2336-2342.

52. Joly BS, Vanhoorelbeke K, Veyradier A. Understanding therapeutic targets in thrombotic thrombocytopenic purpura. Intensive Care Med 2017;43(9):1398-1400. 


\section{Legends to figures}

\section{Figure 1: Design of the study.}

Analysis of the French Thrombotic MicroAngiopathies (TMA) Registry from January 1 st 2000 to June 1 st 2017 reported 7309 adults and 1112 children (age $<18$ at inclusion) with a TMA suspicion. Of these, 1608 adults (22\%) and 87 children (7.8\%) exhibited a first TMA episode related to a severe ADAMTS13 functional deficiency (activity $<10 \mathrm{IU} / \mathrm{dL}$ ) defined as thrombotic thrombocytopenic purpura (TTP). Acquired TTP, unavailable biological sample or missing data during follow-up and genotypic investigations in progress were exclusion criteria. Our cohort of interest consisted in 22 patients with an adult-onset and 34 patients with a child-onset congenital TTP (Upshaw-Schulman syndrome) from 20 and 31 families, respectively.

Figure 2: Distribution of ADAMTS13 mutations in 51 French families with child-onset or adultonset Upshaw-Schulman syndrome (USS).

ADAMTS13 consists of $\mathrm{N}$-terminal (signal peptide, propeptide, metalloprotease, disintegrin, first thrombospondin type 1 repeat, cys-rich and spacer) and C-terminal (seven thrombospondin type 1 repeats, two CUB domains) domains.

Panel 2A presents 43 distinct sequence variations in 31 French families (34 patients) with child-onset USS. Missense mutations (top) were the most frequent $(56 \%, 24 / 43)$ while truncating sequence variations (bottom) including nonsense mutations (9\%), frameshift/splice mutations (30\%) and deletions $(5 \%)$ represented $44 \%$ (19/43) of all sequence variations. Overall, $56 \%(24 / 43)$ and $42 \%(18 / 43)$ of these sequence variations were located in the part of ADAMTS13 gene coding for the $\mathrm{N}$-terminal part and the C-terminal part of the protein, respectively; only $2 \%$ (1/43) consisted in one large deletion of ADAMTS13 gene.

Panel 2B presents 20 distinct sequence variations in 20 French families (22 patients) with adult-onset USS. Missense mutations (top) represented 60\% (12/20) while truncating sequence variations (bottom) were $40 \%(8 / 20)$. Sixty percent (12/20) of ADAMTS13 sequence variations were located in the $\mathrm{N}$-term part of ADAMTS13.

All missense mutations were predicted in silico to be deleterious. Truncating sequence variations were predicted in silico to be certainly deleterious, inducing the destruction of mRNA by nonsense-mediated mRNA decay and thus a non expression of ADAMTS13 gene.

Abbreviations. int: intron, del: deletion, ins: insertion, acc splice: acceptor splice, *: stop codon.

Figure 3. ADAMTS13 genotypic analysis in $\mathbf{5 6}$ patients with Upshaw-Schulman syndrome (USS). Sequence variations of ADAMTS13 in child-onset and adult-onset USS are represented in black and white, respectively.

3A. Proportion of patients with miscellaneous combinations of ADAMTS13 gene sequence variations as a function of the localization of the amino-acid change on the protein ( $\mathrm{N}$-term or $\mathrm{C}$-term domain for missense mutations, "other" for unpredictable localization linked to truncating mutation). 
3B. Proportion of patients with miscellaneous combinations of ADAMTS13 gene sequence variations as a function of missense or truncating features.

Figure 4. ADAMTS13 phenotypic analysis in 56 patients with Upshaw-Schulman syndrome (USS).

ADAMTS13 antigen (4A) and activity (4B) distributions were represented in child-onset (black circle) and adult-onset (white circle) patients with USS. The low limit of detection of ADAMTS13 antigen (3H9based ELISA) was $0.03 \mu \mathrm{g} / \mathrm{mL}$ (dotted black line). The low limit of detection of ADAMTS13 activity (chromogenic VWF73 ELISA) was $3 \mathrm{IU} / \mathrm{dL}$ (dotted black line). The threshold of ADAMTS13 activity for diagnosis of thrombotic thrombocytopenic purpura (TTP) was $10 \mathrm{lU} / \mathrm{dL}$ (dotted grey line).

ADAMTS13 conformation was studied in 16 patients with either child-onset (4C) or adult-onset (4D) USS, before and after addition of anti-CUB1 antibody 17G2. A conformation index $<0.5$ corresponds to a folded ADAMTS13; a conformation index $>0.5$ corresponds to an open ADAMTS13. ADAMTS13 genotype in 5 child-onset and 11 adult-onset USS patients are indicated on the right side of panels $4 \mathrm{C}$ and 4D, respectively. NHP: Normal Human Plasma. 
Table 1. Demographic and clinical features of the first thrombotic thrombocytopenic purpura (TTP) episode and long-term follow-up in 34 patients with child-onset Upshaw-Schulman syndrome.

\begin{tabular}{|c|c|}
\hline Demographic features of the inaugural TTP episode & $\begin{array}{l}\mathrm{n}(\%) \\
(\mathrm{n} \text { total: } 34)\end{array}$ \\
\hline Female & $18(53 \%)$ \\
\hline Male & $16(47 \%)$ \\
\hline Presence of comorbidities & $11(32 \%)$ \\
\hline Familial consanguinity & $11(32 \%)$ \\
\hline TMA symptoms at birth & $26(76 \%)$ \\
\hline $\begin{array}{l}\text { Age at first TTP episode (acute phase) } \\
\text { - neonatal period (before day } 28 \text { ) } \\
\text { - post-neonatal period (day } 28-1 \text { year) } \\
\text { - childhood (>1 year }-<18 \text { years) } \\
\text { - adulthood (>18 years) * }\end{array}$ & $\begin{array}{l}3(9 \%) \\
12(35 \%) \\
17(50 \%) \\
2(6 \%)\end{array}$ \\
\hline \multicolumn{2}{|l|}{ Follow-up (median of 11 years) } \\
\hline Death & $0(0 \%)$ \\
\hline $\begin{array}{l}<10 \text { TTP relapses } \\
\text { Chronic disease ( } \geq 10 \text { TTP relapses) }\end{array}$ & $\begin{array}{l}27(79 \%) \\
7(21 \%)\end{array}$ \\
\hline $\begin{array}{l}\text { Trigger for acute phase of TTP } \\
\text { - infection / vaccination } \\
\text { - pregnancy (transition child/adult) } \\
\text { - none }\end{array}$ & $\begin{array}{l}23(68 \%) \\
4(12 \%) \\
10(29 \%)\end{array}$ \\
\hline $\begin{array}{l}\text { TTP sequelae } \\
\text { - renal } \\
\text { - neurological } \\
\text { - cardiac }\end{array}$ & $\begin{array}{l}16(47 \%) \\
7(21 \%) \\
7(21 \%) \\
8(24 \%)\end{array}$ \\
\hline \multicolumn{2}{|l|}{ Treatment } \\
\hline Prophylactic plasmatherapy & $28(82 \%)$ \\
\hline
\end{tabular}

(TTP: thrombotic thrombocytopenic purpura, TMA: thrombotic microangiopathy)

* Two patients exhibited a first identified TTP episode in adulthood during a first pregnancy but they had TMA symptoms requiring exchange blood transfusion at birth and an unexplained fluctuant thrombocytopenia in childhood (explaining the child-onset classification). 
Table 2. Genetic analysis of ADAMTS13 gene in 34 patients (31 families) with child-onset Usphaw-Schulman syndrome.

\begin{tabular}{|c|c|c|c|c|c|c|c|}
\hline Sequence change & $\begin{array}{l}\text { Exon/ } \\
\text { Intron }\end{array}$ & $\begin{array}{l}\text { Amino acid } \\
\text { change }\end{array}$ & $\begin{array}{l}\text { Domain of } \\
\text { ADAMTS13 }\end{array}$ & $\begin{array}{l}\text { Sequence } \\
\text { variation }\end{array}$ & Status & $\begin{array}{c}\mathbf{N} \text { of } \\
\text { alleles } \S \\
(\%)\end{array}$ & $\begin{array}{l}\text { Reported } \\
\text { in the } \\
\text { literature }\end{array}$ \\
\hline c. $330+3 G>C$ & Intron 3 & p.? & & splice site & HTZ & $1(1.5 \%)$ & $\mathrm{NO}$ \\
\hline c.687-7C>A & Intron 6 & p.? & & splice site & HTZ & $1(1.5 \%)$ & $\mathrm{NO}$ \\
\hline c. $988-2 A>G$ & Intron 8 & p.? & & splice site & HTZ & $1(1.5 \%)$ & $\mathrm{NO}$ \\
\hline c.1308+2_1308+5del & Intron 11 & p.? & & splice site & HTZ & $1(1.5 \%)$ & YES \\
\hline c. $1309-1 \mathrm{G}>\mathrm{A}$ & Intron 11 & p.? & & splice site & HTZ & $1(1.5 \%)$ & YES \\
\hline c. $1584+2 \mathrm{~T}>\mathrm{A}$ & Intron 13 & p.? & & splice site & HTZ & $1(1.5 \%)$ & NO \\
\hline c. $1585-1 \mathrm{G}>\mathrm{C}$ & Intron 13 & p.? & & splice site & HTZ & $1(1.5 \%)$ & NO \\
\hline c. $2104+1 G>A$ & Intron 17 & p.? & & splice site & HMZ & $2(2.9 \%)$ & NO \\
\hline c. $3892+1 G>A$ & Intron 27 & p.? & & splice site & HMZ & $2(2.9 \%)$ & NO \\
\hline Large deletion & Ex1-5'UTR & p.? & & deletion & HTZ & $1(1.5 \%)$ & $\mathrm{NO}$ \\
\hline c.22dupG & Exon 1 & p.Ala8Glyfs ${ }^{*} 131$ & & frameshift & HTZ & $1(1.5 \%)$ & NO \\
\hline c. $237 \mathrm{C}>\mathrm{G}$ & Exon 3 & p.lle79Met & metalloprotease & missense & HTZ & $1(1.5 \%)$ & YES \\
\hline c. $607 \mathrm{~T}>\mathrm{C}$ & Exon 6 & p.Ser203Pro & metalloprotease & missense & HTZ & $1(1.5 \%)$ & YES \\
\hline c. $655 \mathrm{G}>\mathrm{C}$ & Exon 6 & p.Gly219Arg & metalloprotease & missense & $\mathrm{HTZ}$ & $1(1.5 \%)$ & NO \\
\hline c. $803 \mathrm{G}>\mathrm{C}$ & Exon 7 & p.Arg268Pro & metalloprotease & missense & HTZ & $1(1.5 \%)$ & YES \\
\hline c.825-10_843del29 & Exon 8 & p.? & & deletion & HTZ & $2(2.9 \%)$ & YES \\
\hline c. $844 G>C$ & Exon 8 & p.Val282Leu & metalloprotease & missense & HTZ & $2(2.9 \%)$ & NO \\
\hline c. $964 T>G$ & Exon 8 & p.Cys322Gly & disintegrine-like & missense & HTZ & $1(1.5 \%)$ & YES \\
\hline c. $1193 \mathrm{G}>\mathrm{A}$ & Exon 10 & p.Arg398His & TSP1-1 & missense & HTZ & $1(1.5 \%)$ & YES \\
\hline c. $1308 \mathrm{G}>\mathrm{C}$ & Exon 11 & p.Gln436His & TSP1-1 & missense & HMZ & $2(2.9 \%)$ & YES \\
\hline c. $1312 T>C$ & Exon 12 & p.Cys438Arg & TSP1-1 & missense & HMZ & $2(2.9 \%)$ & NO \\
\hline c. $1328 \mathrm{~T}>\mathrm{C}$ & Exon 12 & p.Leu443Pro & CYS rich & missense & HTZ & $2(2.9 \%)$ & $\mathrm{NO}$ \\
\hline c. $1409 \mathrm{G}>\mathrm{A}$ & Exon 12 & p.Trp470* & & nonsense & HTZ & $2(2.9 \%)$ & $\mathrm{NO}$ \\
\hline c. $1520 \mathrm{G}>\mathrm{A}$ & Exon 13 & p.Arg507GIn & CYS rich & missense & HTZ/HMZ & $3(4.4 \%)$ & YES \\
\hline c. $1643 G>T$ & Exon 14 & p.Cys548Phe & CYS rich & missense & $\mathrm{HTZ}$ & $1(1.5 \%)$ & $\mathrm{NO}$ \\
\hline c. $1787 \mathrm{C}>\mathrm{T}$ & Exon 16 & p.Ala596Val & spacer & missense & $\mathrm{HTZ} / \mathrm{HMZ}$ & $3(4.4 \%)$ & YES \\
\hline c.1908dupG & Exon 16 & p.Leu637Alafs $* 18$ & & frameshift & $\mathrm{HTZ}$ & $1(1.5 \%)$ & NO \\
\hline c. $2074 \mathrm{C}>\mathrm{T}$ & Exon 17 & p.Arg692Cys & TSP1-2 & missense & HMZ & $2(2.9 \%)$ & YES \\
\hline c. $2085 C>G$ & Exon 17 & p.Cys695Trp & TSP1-2 & missense & HTZ & $1(1.5 \%)$ & $\mathrm{NO}$ \\
\hline c.2203G>T & Exon 18 & p.Glu735* & & nonsense & HMZ & $4(5.8 \%)$ & YES \\
\hline c. $2260 \mathrm{~T}>\mathrm{C}$ & Exon 19 & p.Cys754Arg & TSP1-3 & missense & HMZ & $2(2.9 \%)$ & YES \\
\hline c. $2272 \mathrm{~T}>\mathrm{C}$ & Exon 19 & p.Cys758Arg & TSP1-3 & missense & HTZ & $2(2.9 \%)$ & YES \\
\hline c. $2404 C>T$ & Exon 19 & p.GIn802* & & nonsense & HTZ & $1(1.5 \%)$ & $\mathrm{NO}$ \\
\hline c. $2723 G>C$ & Exon 21 & p.Cys908Ser & TSP1-5 & missense & HTZ & $1(1.5 \%)$ & YES \\
\hline c. $2836 \mathrm{~T}>\mathrm{C}$ & Exon 22 & p.Cys946Arg & TSP1-5 & missense & HTZ & $1(1.5 \%)$ & NO \\
\hline c. $2929 \mathrm{~T}>\mathrm{C}$ & Exon 23 & p.Cys977Arg & TSP1-6 & missense & HTZ & $1(1.5 \%)$ & $\mathrm{NO}$ \\
\hline c. $3070 T>G$ & Exon 24 & p.Cys1024Gly & TSP1-7 & missense & HMZ & $4(5.8 \%)$ & YES \\
\hline c.3254_3255delCT & Exon 25 & p.Ser1085Cysfs*12 & & frameshift & HTZ & $1(1.5 \%)$ & YES \\
\hline c.3390T $>\mathrm{G}$ & Exon 25 & p.Cys1130Trp & TSP1-8 & missense & HMZ & $2(2.9 \%)$ & NO \\
\hline c. $3616 C>T$ & Exon 26 & p.Arg1206* & & nonsense & HTZ/HMZ & $5(7.4 \%)$ & YES \\
\hline c. $3655 \mathrm{C}>\mathrm{T}$ & Exon 26 & p.Arg1219Trp & CUB-1 & missense & HTZ & $1(1.5 \%)$ & YES \\
\hline c. $4085 \mathrm{~A}>\mathrm{T}$ & Exon 29 & p.Asp1362Val & CUB-2 & missense & HTZ & $1(1.5 \%)$ & YES \\
\hline c.4143dupA & Exon 29 & p.Glu1382Argfs*6 & & frameshift & HTZ & $3(4.4 \%)$ & YES \\
\hline
\end{tabular}

$\S$ total number of alleles $=68$

(HMZ: homozygous; HTZ: heterozygous) 
Table 3. Genetic analysis of ADAMTS13 gene in 22 patients (20 families) with adult-onset Usphaw-Schulman syndrome.

\begin{tabular}{|c|c|c|c|c|c|c|c|}
\hline Sequence change & Exon/Intron & $\begin{array}{l}\text { Amino acid } \\
\text { change }\end{array}$ & $\begin{array}{l}\text { Domain of } \\
\text { ADAMTS13 }\end{array}$ & $\begin{array}{l}\text { Sequence } \\
\text { variation }\end{array}$ & Status & $\begin{array}{l}\mathbf{N} \text { of } \\
\text { alleles } \S \\
(\%)\end{array}$ & $\begin{array}{l}\text { Reported in } \\
\text { the } \\
\text { literature }\end{array}$ \\
\hline c.173-14_173-2del12 & Intron 2 & p.? & & splice site & HTZ & $1(2.3 \%)$ & NO \\
\hline c. $988-2 A>C$ & Intron 8 & p.? & & splice site & HTZ & $1(2.3 \%)$ & YES \\
\hline c. $1309-25 \mathrm{C}>\mathrm{A}$ & Intron 11 & p.? & & splice site & HTZ & $1(2.3 \%)$ & YES \\
\hline c. $262 \mathrm{G}>\mathrm{C}$ & Exon 3 & p.Val88Leu & metalloprotease & missense & HTZ & $1(2.3 \%)$ & YES \\
\hline c. $283 \mathrm{G}>\mathrm{C}$ & Exon 3 & p.Ala95Pro & metalloprotease & missense & HTZ & $2(4.5 \%)$ & YES \\
\hline c. $460 \mathrm{G}>\mathrm{A}$ & Exon 5 & p.Val154lle & metalloprotease & missense & HTZ & $1(2.3 \%)$ & $\mathrm{NO}$ \\
\hline c.559G >C & Exon 6 & p.Asp187His & metalloprotease & missense & HTZ & $1(2.3 \%)$ & YES \\
\hline c.706G $>\mathrm{T}$ & Exon 7 & p.Gly236Cys & metalloprotease & missense & HMZ & $2(4.5 \%)$ & YES \\
\hline c. $1058 \mathrm{C}>\mathrm{T}$ & Exon 9 & p.Pro353Leu & disintegrin & missense & HTZ & $1(2.3 \%)$ & YES \\
\hline c.1408dup & Exon 12 & p.Trp470Leufs*64 & & frameshift & HTZ & $1(2.3 \%)$ & YES \\
\hline c.1651G>T & Exon 14 & p.Asp551Tyr & Cys-rich & missense & HTZ & $1(2.3 \%)$ & $\mathrm{NO}$ \\
\hline c. $1892 \mathrm{C}>\mathrm{T}$ & Exon 16 & p.Ala631Val & spacer & missense & HTZ & $2(4.5 \%)$ & YES \\
\hline c. $2434 \mathrm{G}>\mathrm{T}$ & Exon 20 & p.Glu812* & & nonsense & HTZ & $2(4.5 \%)$ & YES \\
\hline c.2455delG & Exon 20 & p.Ala819Leufs ${ }^{\star} 24$ & & frameshift & HTZ & $1(2.3 \%)$ & YES \\
\hline c. $2746 C>T$ & Exon 22 & p.Arg916Cys & TSP1-5 & missense & HTZ & $1(2.3 \%)$ & YES \\
\hline c. $2890 \mathrm{G}>\mathrm{A}$ & Exon 23 & p.Val964Met & TSP1-5 & missense & HTZ & $1(2.3 \%)$ & \\
\hline c. $3178 \mathrm{C}>\mathrm{T}$ & Exon 24 & p.Arg1060Trp & TSP1-7 & missense & $\mathrm{HTZ} / \mathrm{HMZ}$ & $\begin{array}{l}21 \\
(48 \%)\end{array}$ & YES \\
\hline c.3198_3199del & Exon 24 & p.Cys1067Serfs*30 & & frameshift & HTZ & $1(2.3 \%)$ & YES \\
\hline c. $3313 C>T$ & Exon 25 & p.G $\ln 1105^{*}$ & & nonsense & HTZ & $1(2.3 \%)$ & YES \\
\hline c. $4135 \mathrm{~T}>\mathrm{C}$ & Exon 29 & p.Trp1379Arg & CUB-2 & missense & HTZ & $1(2.3 \%)$ & YES \\
\hline
\end{tabular}

§ Total number of alleles: 44 .

(HMZ: homozygous; HTZ: heterozygous) 
Table 4. ADAMTS13 conformation according to ADAMTS13 gene sequence variations in 16 patients with Upshaw-Schulman syndrome.

\begin{tabular}{|c|c|c|c|c|c|}
\hline $\begin{array}{l}\text { Patients } \\
\mathrm{N}^{\circ}\end{array}$ & $\begin{array}{l}\text { Age-onset } \\
\text { of USS }\end{array}$ & $\begin{array}{c}\text { ADAMTS13 genotype } \\
\text { seq. variation / ADAMTS13 } \\
\text { domain } \\
\text { (allele } 1 \text { and allele } 2 \text { ) }\end{array}$ & $\begin{array}{c}\text { ADAMTS13 } \\
\text { antigen } \\
(3 \mathrm{H} 9-\text { based } \\
\text { ELISA }(\mu \mathrm{g} / \mathrm{mL})^{*}\end{array}$ & $\begin{array}{c}\text { Basal } \\
\text { ADAMTS13 } \\
\text { conformation } \\
(-17 G 2)\end{array}$ & $\begin{array}{c}\text { ADAMTS13 } \\
\text { conformation } \\
\text { after pre- } \\
\text { incubation } \\
\text { with 17G2 }\end{array}$ \\
\hline Child 10 & child & $\begin{array}{l}\text { p. Ala596Val / spacer } \\
\text { p. Ala596Val / spacer }\end{array}$ & 0.068 & folded & folded \\
\hline Child 13 & child & $\begin{array}{c}\text { c.1309-1G>A } \\
\text { p.Cys908Ser / TSP1-5 }\end{array}$ & 0.050 & open & open \\
\hline Child 32 & child & $\begin{array}{l}\text { p.Cys1024Gly / TSP1-7 } \\
\text { p.Cys1024Gly / TSP1-7 }\end{array}$ & 0.058 & folded & folded \\
\hline Adult 02 & adult & $\begin{array}{c}\text { SNP (p.Arg7Trp, p.GIn448Glu, } \\
\text { p.Pro618Ala, p.Ala732Val, } \\
\text { p.Ala1033Thr) } \\
\text { p.Arg1060Trp / TSP1-7 }\end{array}$ & 0.158 & folded & open \\
\hline Adult 20 & adult & $\begin{array}{c}\text { SNP (p.Arg7Trp, p.GIn448Glu, } \\
\text { p.Pro618Ala, p.Ala732Val, } \\
\text { p.Ala1033Thr) } \\
\text { p.Arg1060Trp / TSP1-7 }\end{array}$ & 0.201 & folded & open \\
\hline Adult 08 & adult & $\begin{array}{l}\text { p.Val88Leu / Metalloprotease } \\
\text { p.Arg1060Trp / TSP1-7 }\end{array}$ & 0.143 & folded & folded \\
\hline Adult 04 & adult & $\begin{array}{l}\text { p.Pro353Leu / Disintegrin } \\
\text { p.Arg1060Trp / TSP1-7 }\end{array}$ & 0.043 & folded & folded \\
\hline Adult 19 & adult & $\begin{array}{c}\text { p.Trp470Leufs*64 } \\
\text { p.Arg1060Trp / TSP1-7 }\end{array}$ & 0.054 & folded & folded \\
\hline Adult 10 & adult & $\begin{array}{l}\text { p.Asp551Tyr / Cys-rich } \\
\text { p.Arg1060Trp / TSP1-7 }\end{array}$ & 0.051 & folded & folded \\
\hline Adult 01 & adult & $\begin{array}{c}\text { p.Glu812* } \\
\text { p.Arg1060Trp / TSP1-7 }\end{array}$ & 0.122 & folded & folded \\
\hline Adult 15 & adult & $\begin{array}{l}\text { p.Arg916Cys / TSP1-5 } \\
\text { p.Arg1060Trp / TSP1-7 }\end{array}$ & 0.034 & folded & folded \\
\hline Adult 11 & adult & $\begin{array}{l}\text { p.Arg1060Trp / TSP1-7 } \\
\text { p.Arg1060Trp / TSP1-7 }\end{array}$ & 0.053 & folded & folded \\
\hline Adult 03 & adult & $\begin{array}{l}\text { p.Arg1060Trp / TSP1-7 } \\
\text { p.Arg1060Trp / TSP1-7 }\end{array}$ & 0.054 & folded & folded \\
\hline Adult 14 & adult & $\begin{array}{l}\text { c.173-14_173-2del12 } \\
\text { p.Cys1067Serfs*30 }\end{array}$ & 0.109 & folded & folded \\
\hline Child 30 & child & $\begin{array}{l}\text { p. Arg1206* } \\
\text { p. Arg1206* }\end{array}$ & 0.053 & open & folded \\
\hline Child 08 & child & $\begin{array}{c}\text { c.988-2A>G } \\
\text { p. Asp1362Val / CUB-2 }\end{array}$ & 0.057 & folded & folded \\
\hline NHP & - & $\begin{array}{l}\text { WT } \\
\text { WT }\end{array}$ & 1.000 & folded & open \\
\hline
\end{tabular}

USS: Upshaw-Schulman syndrome, NHP: normal human plasma, WT: wild type.

*All patients exhibited similar ADAMTS13 antigen levels when re-checked with the 4B9-based ELISA. 


\section{ADAMTS13 gene mutations influence ADAMTS13 conformation and disease age-onset in the French cohort of Upshaw-Schulman syndrome.}

\section{Running head: French cohort of Upshaw-Schulman syndrome}

Bérangère S. Joly1,2, Pierre Boisseau,, Elien Roose4, Alain Stepanian1,2, Nathalie Biebuyck5, Julien Hogan6, François Provot7, Yahsou Delmas8, Céline Garrec3, Karen Vanhoorelbeke4, Paul Coppos, Agnès Veyradier 1,2 ; on behalf of the French Reference Center for Thrombotic Microangiopathies.

1 EA3518, Institut Universitaire d'Hématologie, Université Paris Diderot, Hôpital Saint-Louis, Assistance Publique - Hôpitaux de Paris, Paris, France

2 Service d'Hématologie biologique, Université Paris Diderot, Hôpital Lariboisière, Assistance Publique - Hôpitaux de Paris, Paris, France

3 Service de Génétique médicale, Hôpital Hôtel-Dieu, CHU de Nantes, Nantes, France

4 Laboratory for Thrombosis Research, IRF Life Sciences, KU Leuven Kulak Campus Kortrijk, Kortrijk, Belgium

5 Service de néphrologie pédiatrique, Hôpital Necker, Assistance Publique - Hôpitaux de Paris, Paris, France

6 Service de néphrologie pédiatrique, Hôpital Robert Debré, Assistance Publique - Hôpitaux de Paris, Paris, France

7 Service de néphrologie, CHRU de Lille, Lille, France

${ }_{8}$ Service de néphrologie, CHU Pellegrin, Bordeaux, France

9 Département d'Hématologie Clinique, Université Pierre et Marie Curie, Hôpital Saint-Antoine, Assistance Publique - Hôpitaux de Paris, Paris, France

B.S. Joly and P. Boisseau contributed equally to this work.

\section{SUPPLEMENTAL SECTION}


Suppl. Table 1. Demographic data and ADAMTS13 phenotypic investigations in 34 patients (31 families) with child-onset Usphaw-Schulman syndrome.

\begin{tabular}{|c|c|c|c|c|c|c|c|c|c|}
\hline \multirow{3}{*}{ Patients } & \multicolumn{4}{|c|}{ Demographic features } & \multicolumn{5}{|c|}{ Phenotypic investigations of ADAMTS13 } \\
\hline & \multirow[t]{2}{*}{ Sex } & \multirow{2}{*}{$\begin{array}{c}\text { Age at } \\
\text { time of the } \\
\text { study } \\
(2017) \\
\text { (years) }\end{array}$} & \multirow[t]{2}{*}{ Comorbidities } & \multirow[t]{2}{*}{ Family } & \multirow{2}{*}{$\begin{array}{l}\text { ADAMTS13 } \\
\text { activity } \\
\text { (reference } \\
\text { methods*) } \\
\text { (IU/dL) }\end{array}$} & \multirow{2}{*}{$\begin{array}{l}\text { ADAMTS13 } \\
\text { activity } \\
\text { (Chr- } \\
\text { VWF73) } \\
\text { (IU/dL) }\end{array}$} & \multirow{2}{*}{$\begin{array}{c}\text { Anti- } \\
\text { ADAMTS13 } \\
\text { autoantibodies }\end{array}$} & \multicolumn{2}{|c|}{$\begin{array}{c}\text { ADAMTS13 } \\
\text { antigen }(\mu \mathrm{g} / \mathrm{mL})\end{array}$} \\
\hline & & & & & & & & $\begin{array}{l}\text { Commer- } \\
\text { cial } \\
\text { assay }\end{array}$ & $\begin{array}{c}3 \mathrm{H} 9 \\
\text { based } \\
\text { ELISA }\end{array}$ \\
\hline Child 01 & $\mathrm{M}$ & 22 & obesity & none & $<10$ & $<3$ & negative & $<0.065$ & $<$ LLD \\
\hline Child 02 & $\mathrm{M}$ & 11 & none & none & $<10$ & $<3$ & negative & $<0.065$ & $<$ LLD \\
\hline Child 03 & $\mathrm{~F}$ & 10 & none & consanguinity & $<10$ & $<3$ & negative & $<0.065$ & $<$ LLD \\
\hline Child 04 & $\mathrm{M}$ & 8 & none & none & $<10$ & $<3$ & negative & $<0.065$ & $<$ LLD \\
\hline Child 05 & M & 24 & $\begin{array}{c}\text { G6PD } \\
\text { deficiency }\end{array}$ & consanguinity & $<10$ & $<3$ & negative & $<0.065$ & $<$ LLD \\
\hline Child 06 & $\mathrm{~F}$ & 36 & none & none & $<10$ & $<3$ & negative & $<0.065$ & $<$ LLD \\
\hline Child 07 & $\mathrm{~F}$ & 11 & MCP mutation & none & $<10$ & $<3$ & negative & $<0.065$ & $<L L D$ \\
\hline Child 08 & $\mathrm{~F}$ & 34 & none & none & $<10$ & $<3$ & negative & $<0.065$ & 0.057 \\
\hline Child 09 & $\mathrm{~F}$ & 19 & $\begin{array}{c}\text { mutation in } \\
\text { CFH }\end{array}$ & none & $<10$ & $<3$ & negative & $<0.065$ & $<$ LLD \\
\hline Child 10 & $\mathrm{~F}$ & 22 & none & none & $<10$ & $<3$ & negative & $<0.065$ & 0.068 \\
\hline Child 11 & $M$ & 31 & dialysis & none & $<10$ & $<3$ & negative & $<0.065$ & $<$ LLD \\
\hline Child 12 & $\mathrm{~F}$ & 34 & none & none & $<10$ & $<3$ & negative & $<0.065$ & $<L L D$ \\
\hline Child 13 & $M$ & 40 & $\begin{array}{c}\text { kidney } \\
\text { transplantation }\end{array}$ & consanguinity & $<10$ & N/A & negative & $<0.065$ & 0.050 \\
\hline Child 14 & $\mathrm{~F}$ & 23 & $\begin{array}{l}\text { hypothyroidism } \\
\text { (Hashimoto) }\end{array}$ & none & $<10$ & $<3$ & negative & $<0.065$ & $<$ LLD \\
\hline Child 15 & $\mathrm{M}$ & 43 & none & none & $<10$ & $<3$ & negative & $<0.065$ & $<$ LLD \\
\hline Child 16 & $\mathrm{~F}$ & 5 & none & consanguinity & $<10$ & $<3$ & negative & $<0.065$ & $<$ LLD \\
\hline Child 17 & $\mathrm{~F}$ & 25 & $\begin{array}{c}\text { mutation in } \\
\mathrm{CFH}\end{array}$ & none & $<10$ & $<3$ & negative & $<0.065$ & $<$ LLD \\
\hline Child 18 & $\mathrm{M}$ & 12 & none & none & $<10$ & $<3$ & negative & $<0.065$ & $<$ LLD \\
\hline Child 19 & $\mathrm{~F}$ & 1 & none & consanguinity & $<10$ & $<3$ & negative & $<0.065$ & $<$ LLD \\
\hline Child 20 & $\mathrm{M}$ & 3 & none & none & $<10$ & $<3$ & negative & $<0.065$ & $<$ LLD \\
\hline Child 21 & $\mathrm{~F}$ & 34 & none & consanguinity & $<10$ & $<3$ & negative & $<0.065$ & $<$ LLD \\
\hline Child 22 & $\mathrm{M}$ & 43 & none & none & $<10$ & $<3$ & negative & $<0.065$ & $<L L D$ \\
\hline Child 23 & $\mathrm{M}$ & 22 & none & consanguinity & $<10$ & $<3$ & negative & $<0.065$ & $<$ LLD \\
\hline Child 24 & $\mathrm{~F}$ & 42 & none & none & $<10$ & $<3$ & negative & $<0.065$ & $<$ LLD \\
\hline Child 25 & $\mathrm{~F}$ & 8 & none & consanguinity & $<10$ & $<3$ & negative & $<0.065$ & $<L L D$ \\
\hline Child 26 & $\mathrm{~F}$ & 46 & none & none & $<10$ & $<3$ & negative & $<0.065$ & $<$ LLD \\
\hline Child 27 & $\mathrm{M}$ & 8 & none & none & $<10$ & $<3$ & negative & $<0.065$ & $<$ LLD \\
\hline Child 28 & $\mathrm{~F}$ & 9 & $\begin{array}{c}\text { Moyamoya } \\
\text { disease }\end{array}$ & none & $<10$ & $<3$ & negative & $<0.065$ & $<$ LLD \\
\hline Child 29 & $\mathrm{~F}$ & 16 & hypothyroidism & consanguinity & $<10$ & $<3$ & negative & $<0.065$ & $<$ LLD \\
\hline Child 30 & $M$ & 12 & $\begin{array}{l}\text { minor alpha } \\
\text { thalassemia }\end{array}$ & consanguinity & $<10$ & $<3$ & negative & $<0.065$ & 0.053 \\
\hline Child 31 & $\mathrm{M}$ & 15 & none & none & $<10$ & $<3$ & negative & $<0.065$ & $<$ LLD \\
\hline Child 32 & $\mathrm{~F}$ & 16 & none & none & $<10$ & $<3$ & negative & $<0.065$ & 0.058 \\
\hline Child 33 & $\mathrm{M}$ & 49 & none & none & $<10$ & $\mathrm{~N} / \mathrm{A}$ & negative & N/A & N/A \\
\hline Child 34 & $M$ & 32 & none & consanguinity & $<10$ & $<3$ & negative & $<0.065$ & $<L L D$ \\
\hline
\end{tabular}

CFH: complement factor H; MCP: membrane cofactor protein; N/A: not available; LLD: low limit of detection.

* Reference methods for ADAMTS13 activity measurement: FRETS-VWF73 (Kokame et al, BJH 2005), full-length

VWF ELISA (Veyradier et al, Blood 2001), full-length VWF CBA (Gerritsen et al, Thromb Haemost 1999). 
Suppl. Table 2. Clinical features of $\mathbf{3 4}$ patients with child-onset Usphaw-Schulman syndrome.

\begin{tabular}{|c|c|c|c|c|c|c|c|c|c|}
\hline \multirow[t]{2}{*}{ Patients } & \multirow[t]{2}{*}{$\begin{array}{l}\text { USS symptoms } \\
\text { at birth * }\end{array}$} & \multirow{2}{*}{$\begin{array}{c}\text { Age at first } \\
\text { USS acute } \\
\text { phase }\end{array}$} & \multirow[t]{2}{*}{$\begin{array}{l}\text { Follow-up } \\
\text { (years) }\end{array}$} & \multirow{2}{*}{$\begin{array}{l}\text { Number of } \\
\text { TTP } \\
\text { relapses*** }^{*}\end{array}$} & \multirow{2}{*}{$\begin{array}{c}\text { Triggering } \\
\text { factor of } \\
\text { acute phase } \\
\text { of TTP }\end{array}$} & \multicolumn{2}{|c|}{$\begin{array}{c}\text { Clinical features of TTP acute } \\
\text { phases }\end{array}$} & \multirow[t]{2}{*}{$\begin{array}{c}\text { TTP } \\
\text { sequelae }\end{array}$} & \multirow[t]{2}{*}{ Plasmatherapy**** } \\
\hline & & & & & & $\begin{array}{l}\text { Hematological } \\
\text { features }\end{array}$ & $\begin{array}{c}\text { Visceral } \\
\text { ischemia }\end{array}$ & & \\
\hline Child 01 & TMA & $\begin{array}{c}\text { postneonatal } \\
\text { period } \\
(10 \text { months }) \\
\end{array}$ & 22 & 1 & none & $\begin{array}{l}\text { hemolytic anemia } \\
\text { thrombocytopenia }\end{array}$ & none & none & $\begin{array}{l}\text { curative and } \\
\text { prophylactic }\end{array}$ \\
\hline Child 02 & anemia & $\begin{array}{c}\text { childhood } \\
\text { (20 months) }\end{array}$ & 8 & $\begin{array}{c}{[0-5]} \\
(2) \\
\end{array}$ & infection & $\begin{array}{l}\text { hemolytic anemia } \\
\text { thrombocytopenia }\end{array}$ & none & none & curative \\
\hline Child 03 & none & $\begin{array}{c}\text { postneonatal } \\
\text { period } \\
(7 \text { months })\end{array}$ & 9 & $\begin{array}{c}{[5-10]} \\
(6)\end{array}$ & $\begin{array}{l}\text { infection and } \\
\text { vaccine }\end{array}$ & $\begin{array}{l}\text { hemolytic anemia } \\
\text { thrombocytopenia }\end{array}$ & $\begin{array}{c}\text { renal } \\
\text { (proteinuria), } \\
\text { hypertension }\end{array}$ & cardiac disorder & $\begin{array}{l}\text { curative and } \\
\text { prophylactic }\end{array}$ \\
\hline Child 04 & $\begin{array}{l}\text { exchange blood } \\
\text { transfusion }\end{array}$ & $\begin{array}{l}\text { childhood (4 } \\
\text { years, } \\
\text { prophylactic } \\
\text { FFP infusions) }\end{array}$ & 7 & $\begin{array}{c}{[0-5]} \\
(3)\end{array}$ & infection & $\begin{array}{l}\text { hemolytic anemia } \\
\text { thrombocytopenia }\end{array}$ & none & none & $\begin{array}{l}\text { curative and } \\
\text { prophylactic }\end{array}$ \\
\hline Child 05 & none & $\begin{array}{l}\text { childhood } \\
\text { (3 years) }\end{array}$ & 13 & $\begin{array}{c}{[5-10]} \\
(7)\end{array}$ & infection & $\begin{array}{l}\text { hemolytic anemia } \\
\text { thrombocytopenia }\end{array}$ & renal (proteinuria) & none & curative \\
\hline Child 06 & $\begin{array}{l}\text { exchange blood } \\
\text { transfusion }\end{array}$ & $\begin{array}{l}\text { postneonatal } \\
\text { period } \\
(6 \text { months })\end{array}$ & 17 & $\begin{array}{c}{[5-10]} \\
(8)\end{array}$ & infection & $\begin{array}{l}\text { hemolytic anemia } \\
\text { thrombocytopenia }\end{array}$ & $\begin{array}{c}\text { neurological } \\
\text { (intracranial } \\
\text { hypertension), } \\
\text { renal (AKI), } \\
\text { hypertension }\end{array}$ & cardiac disorder & $\begin{array}{l}\text { curative and } \\
\text { prophylactic }\end{array}$ \\
\hline Child 07 & TMA & $\begin{array}{l}\text { postneonatal } \\
\text { period } \\
(10 \text { months }) \\
\end{array}$ & 10 & $\begin{array}{c}{[0-5]} \\
(4)\end{array}$ & infection & $\begin{array}{l}\text { hemolytic anemia } \\
\text { thrombocytopenia }\end{array}$ & renal (proteinuria) & none & $\begin{array}{l}\text { curative and } \\
\text { prophylactic }\end{array}$ \\
\hline Child 08 & none & $\begin{array}{l}\text { childhood } \\
\text { (18 months) }\end{array}$ & 17 & $\begin{array}{l}\text { chronic } \\
\text { disease } \\
\text { (13) }\end{array}$ & infection & $\begin{array}{l}\text { hemolytic anemia } \\
\text { thrombocytopenia }\end{array}$ & $\begin{array}{c}\text { renal }(\mathrm{AKI}) \text {, } \\
\text { neurological } \\
\text { (headaches, } \\
\text { confusion) }\end{array}$ & none & $\begin{array}{l}\text { curative and } \\
\text { prophylactic }\end{array}$ \\
\hline Child 09 & $\begin{array}{l}\text { exchange blood } \\
\text { transfusion }\end{array}$ & $\begin{array}{c}\text { postneonatal } \\
\text { period } \\
(9 \text { months }) \\
\end{array}$ & 17 & $\begin{array}{c}{[5-10]} \\
(5)\end{array}$ & infection & $\begin{array}{l}\text { hemolytic anemia } \\
\text { thrombocytopenia }\end{array}$ & renal (AKI) & none & $\begin{array}{l}\text { curative and } \\
\text { prophylactic }\end{array}$ \\
\hline Child 10 & TMA (aHUS) & $\begin{array}{l}\text { postneonatal } \\
\text { period } \\
(11 \text { months })\end{array}$ & 17 & $\begin{array}{l}\text { chronic } \\
\text { disease } \\
(11)\end{array}$ & infection & $\begin{array}{l}\text { hemolytic anemia } \\
\text { thrombocytopenia }\end{array}$ & $\begin{array}{c}\text { renal (AKI), } \\
\text { neurological } \\
\text { (headaches, } \\
\text { coma, transient } \\
\text { focal defects) }\end{array}$ & none & $\begin{array}{l}\text { curative and } \\
\text { prophylactic }\end{array}$ \\
\hline Child 11 & $\begin{array}{l}\text { exchange blood } \\
\text { transfusion }\end{array}$ & $\begin{array}{l}\text { childhood } \\
\text { (5 years) }\end{array}$ & 16 & $\begin{array}{l}\text { chronic } \\
\text { disease } \\
(>10)\end{array}$ & infection & $\begin{array}{l}\text { hemolytic anemia } \\
\text { thrombocytopenia }\end{array}$ & $\begin{array}{c}\text { renal (chronic } \\
\text { renal failure), } \\
\text { cardiac (impaired } \\
\text { left ventricular } \\
\text { function) } \\
\end{array}$ & $\begin{array}{l}\text { renal and } \\
\text { cardiac } \\
\text { disorders }\end{array}$ & $\begin{array}{l}\text { curative and } \\
\text { prophylactic }\end{array}$ \\
\hline
\end{tabular}


May 31, 2018. R1 TH-18-01-0056. Joly BS et al

\begin{tabular}{|c|c|c|c|c|c|c|c|c|c|}
\hline Child 12 & $\begin{array}{l}\text { exchange blood } \\
\text { transfusion }\end{array}$ & $\begin{array}{l}\text { adulthood } \\
\text { (24 years) }\end{array}$ & 16 & $\begin{array}{c}{[0-5]} \\
(4)\end{array}$ & $\begin{array}{l}\text { pregnancy and } \\
\text { infection }\end{array}$ & $\begin{array}{l}\text { hemolytic anemia } \\
\text { thrombocytopenia }\end{array}$ & $\begin{array}{c}\text { neurological } \\
\text { (headaches, } \\
\text { transient focal } \\
\text { defects), } \\
\text { intrauterine fetal } \\
\text { death }\end{array}$ & $\begin{array}{l}\text { neurological } \\
\text { disorder }\end{array}$ & $\begin{array}{l}\text { curative and } \\
\text { prophylactic } \\
\text { (pregnancy) }\end{array}$ \\
\hline Child 13 & $\begin{array}{l}\text { exchange blood } \\
\text { transfusion }\end{array}$ & $\begin{array}{l}\text { childhood } \\
\text { (5 years) }\end{array}$ & 8 & $\begin{array}{c}\text { chronic } \\
\text { disease } \\
(>14)\end{array}$ & infection & $\begin{array}{l}\text { hemolytic anemia } \\
\text { thrombocytopenia }\end{array}$ & $\begin{array}{l}\text { renal (chronic } \\
\text { renal failure } \\
\text { requiring dialysis } \\
\text { and kidney } \\
\text { transplantation), } \\
\text { neurological } \\
\text { (strokes, } \\
\text { seizures) }\end{array}$ & $\begin{array}{c}\text { renal, } \\
\text { neurological, } \\
\text { cardiac and eye } \\
\text { disorders }\end{array}$ & $\begin{array}{l}\text { curative and } \\
\text { prophylactic }\end{array}$ \\
\hline Child 14 & none & $\begin{array}{c}\text { Adolescent- } \\
\text { hood (17 years) }\end{array}$ & 4 & 2 & none & $\begin{array}{l}\text { hemolytic anemia } \\
\text { thrombocytopenia }\end{array}$ & $\begin{array}{c}\text { neurological } \\
\text { (stroke) }\end{array}$ & $\begin{array}{c}\text { neurological } \\
\text { disorder }\end{array}$ & prophylactic \\
\hline Child 15 & none & $\begin{array}{l}\text { childhood } \\
\text { (8 years) }\end{array}$ & 14 & $\begin{array}{c}{[0-5]} \\
(2)\end{array}$ & none & $\begin{array}{l}\text { hemolytic anemia } \\
\text { thrombocytopenia }\end{array}$ & $\begin{array}{c}\text { neurological } \\
\text { (transient focal } \\
\text { defect) }\end{array}$ & none & $\begin{array}{l}\text { curative and } \\
\text { prophylactic }\end{array}$ \\
\hline Child 16 & $\begin{array}{l}\text { exchange blood } \\
\text { transfusion }\end{array}$ & $\begin{array}{c}\text { childhood } \\
\text { (1 year) }\end{array}$ & 2 & 2 & none & $\begin{array}{l}\text { hemolytic anemia } \\
\text { thrombocytopenia }\end{array}$ & none & none & $\begin{array}{l}\text { curative and } \\
\text { prophylactic }\end{array}$ \\
\hline Child 17 & $\begin{array}{l}\text { exchange blood } \\
\text { transfusion }\end{array}$ & $\begin{array}{c}\text { postneonatal } \\
\text { period } \\
(6 \text { months })\end{array}$ & 16 & $\begin{array}{c}\text { chronic } \\
\text { disease } \\
(>20)\end{array}$ & infection & $\begin{array}{l}\text { hemolytic anemia } \\
\text { thrombocytopenia }\end{array}$ & renal (TMA) & renal disorder & $\begin{array}{c}\text { curative and } \\
\text { prophylactic (and } \\
\text { during pregnancy) }\end{array}$ \\
\hline Child 18 & TMA & $\begin{array}{c}\text { none } \\
\text { (prophylactic } \\
\text { FFP infusions) }\end{array}$ & 11 & $\begin{array}{c}{[0-5]} \\
(0)\end{array}$ & none & $\begin{array}{l}\text { hemolytic anemia } \\
\text { thrombocytopenia }\end{array}$ & $\begin{array}{c}\text { renal (AKI), } \\
\text { neurological } \\
\text { (cerebral } \\
\text { haemorrhage) }\end{array}$ & none & $\begin{array}{l}\text { curative and } \\
\text { prophylactic }\end{array}$ \\
\hline Child 19 & $\begin{array}{l}\text { exchange blood } \\
\text { transfusion }\end{array}$ & $\begin{array}{c}\text { postneonatal } \\
\text { period } \\
(4 \text { months })\end{array}$ & $<1$ & 1 & infection & $\begin{array}{l}\text { hemolytic anemia } \\
\text { thrombocytopenia }\end{array}$ & none & none & $\begin{array}{l}\text { curative and } \\
\text { prophylactic }\end{array}$ \\
\hline Child 20 & $\begin{array}{c}\text { disseminated } \\
\text { intravascular } \\
\text { coagulation }\end{array}$ & $\begin{array}{l}\text { childhood } \\
\text { (1 year) }\end{array}$ & $<1$ & 1 & infection & $\begin{array}{l}\text { hemolytic anemia } \\
\text { thrombocytopenia }\end{array}$ & none & $\begin{array}{c}\text { neurological } \\
\text { and cardiac } \\
\text { disorders }\end{array}$ & $?$ \\
\hline Child 21 & $\begin{array}{l}\text { exchange blood } \\
\text { transfusion }\end{array}$ & $\begin{array}{l}\text { postneonatal } \\
\text { period } \\
(10 \text { months })\end{array}$ & 15 & $\begin{array}{l}{[0-5]} \\
(>2)\end{array}$ & $\begin{array}{l}\text { infection and } \\
\text { pregnancy }\end{array}$ & $\begin{array}{l}\text { hemolytic anemia } \\
\text { thrombocytopenia }\end{array}$ & $\begin{array}{c}\text { renal (AKI), } \\
\text { neurological } \\
\text { (cerebral } \\
\text { vasculitis), } \\
\text { cardiac } \\
\text { (hypertension, } \\
\text { hypertrophy) }\end{array}$ & $\begin{array}{c}\text { renal, } \\
\text { neurological } \\
\text { and cardiac } \\
\text { disorders }\end{array}$ & $\begin{array}{l}\text { curative and } \\
\text { prophylactic }\end{array}$ \\
\hline Child 22 & icterus & $\begin{array}{l}\text { childhood } \\
\text { (5 years) }\end{array}$ & 9 & $\begin{array}{c}\text { chronic } \\
\text { disease } \\
(>15)\end{array}$ & infection & $\begin{array}{l}\text { hemolytic anemia } \\
\text { thrombocytopenia }\end{array}$ & none & none & curative \\
\hline Child 23 & $\begin{array}{c}\text { anemia } \\
\text { thrombocytopenia }\end{array}$ & $\begin{array}{c}\text { neonatal period } \\
\text { ( } 3 \text { weeks) }\end{array}$ & 15 & $\begin{array}{l}{[0-5]} \\
(>2)\end{array}$ & none & $\begin{array}{l}\text { hemolytic anemia } \\
\text { thrombocytopenia }\end{array}$ & none & none & $\begin{array}{l}\text { curative and } \\
\text { prophylactic }\end{array}$ \\
\hline Child 24 & $\begin{array}{l}\text { exchange blood } \\
\text { transfusion }\end{array}$ & $\begin{array}{l}\text { adulthood } \\
\text { (40 years) }\end{array}$ & 1 & $\begin{array}{l}{[0-5]} \\
(>2)\end{array}$ & pregnancy & $\begin{array}{l}\text { hemolytic anemia } \\
\text { thrombocytopenia }\end{array}$ & renal (TMA, AKI) & renal disorder & $\begin{array}{l}\text { curative and } \\
\text { prophylactic }\end{array}$ \\
\hline
\end{tabular}


May 31, 2018. R1 TH-18-01-0056. Joly BS et al

\begin{tabular}{|c|c|c|c|c|c|c|c|c|c|}
\hline Child 25 & TMA (TTP) & $\begin{array}{c}\text { none } \\
\text { (prophylactic } \\
\text { FFP infusions) }\end{array}$ & 7 & $\begin{array}{c}{[0-5]} \\
(0)\end{array}$ & infection & $\begin{array}{l}\text { hemolytic anemia } \\
\text { thrombocytopenia }\end{array}$ & none & renal disorder & $\begin{array}{l}\text { curative and } \\
\text { prophylactic }\end{array}$ \\
\hline Child 26 & $\begin{array}{l}\text { exchange blood } \\
\text { transfusion }\end{array}$ & $\begin{array}{l}\text { childhood } \\
\text { (4 years) }\end{array}$ & 16 & $\begin{array}{c}{[5-10]} \\
(5)\end{array}$ & $\begin{array}{l}\text { infection and } \\
\text { pregnancy }\end{array}$ & $\begin{array}{l}\text { hemolytic anemia } \\
\text { thrombocytopenia }\end{array}$ & $\begin{array}{c}\text { renal (TMA, AKI), } \\
\text { neurological } \\
\text { (confusion, } \\
\text { transient focal } \\
\text { defects), } \\
\text { placental } \\
\text { hematoma }\end{array}$ & none & $\begin{array}{l}\text { curative and } \\
\text { prophylactic }\end{array}$ \\
\hline Child 27 & none & $\begin{array}{l}\text { postneonatal } \\
\text { period }\end{array}$ & 6 & 0 & none & $\begin{array}{l}\text { hemolytic anemia } \\
\text { thrombocytopenia }\end{array}$ & none & none & $\begin{array}{l}\text { curative and } \\
\text { prophylactic }\end{array}$ \\
\hline Child 28 & none & $\begin{array}{c}\text { childhood } \\
\text { (2 years) }\end{array}$ & 6 & $\begin{array}{c}{[0-5]} \\
(1)\end{array}$ & none & $\begin{array}{l}\text { hemolytic anemia } \\
\text { thrombocytopenia }\end{array}$ & $\begin{array}{c}\text { neurological } \\
\text { (transient focal } \\
\text { defect, strokes) }\end{array}$ & $\begin{array}{c}\text { neurological } \\
\text { disorder }\end{array}$ & $\begin{array}{l}\text { curative and } \\
\text { prophylactic }\end{array}$ \\
\hline Child 29 & $\begin{array}{l}\text { hemolytic anemia } \\
\text { thrombocytopenia }\end{array}$ & $\begin{array}{l}\text { childhood } \\
\text { (4 years) }\end{array}$ & 12 & $\begin{array}{c}0-5] \\
(4)\end{array}$ & infection & $\begin{array}{l}\text { hemolytic anemia } \\
\text { thrombocytopenia }\end{array}$ & $\begin{array}{c}\text { renal } \\
\text { (proteinuria), } \\
\text { neurological } \\
\text { (headaches) }\end{array}$ & renal disorder & $\begin{array}{l}\text { curative and } \\
\text { prophylactic }\end{array}$ \\
\hline Child 30 & $\begin{array}{l}\text { exchange blood } \\
\text { transfusion }\end{array}$ & $\begin{array}{l}\text { postneonatal } \\
\text { period } \\
(9 \text { months })\end{array}$ & 12 & $\begin{array}{l}{[0-5]} \\
(1)\end{array}$ & infection & $\begin{array}{l}\text { hemolytic anemia } \\
\text { thrombocytopenia }\end{array}$ & $\begin{array}{l}\text { renal (AKI, } \\
\text { proteinuria) }\end{array}$ & cardiac disorder & $\begin{array}{l}\text { curative and } \\
\text { prophylactic }\end{array}$ \\
\hline Child 31 & icterus & $\begin{array}{c}\text { postneonatal } \\
\text { period } \\
(9 \text { months })\end{array}$ & 9 & $\begin{array}{l}{[0-5]} \\
(1)\end{array}$ & none & $\begin{array}{l}\text { hemolytic anemia } \\
\text { thrombocytopenia }\end{array}$ & none & none & $\begin{array}{l}\text { curative and } \\
\text { prophylactic }\end{array}$ \\
\hline Child 32 & TMA & $\begin{array}{l}\text { childhood } \\
\text { (2 years) }\end{array}$ & 11 & $\begin{array}{c}{[5-10]} \\
(6)\end{array}$ & infection & $\begin{array}{l}\text { hemolytic anemia } \\
\text { thrombocytopenia }\end{array}$ & $\begin{array}{c}\text { renal (AKI), } \\
\text { neurological } \\
\text { (confusion) }\end{array}$ & $\begin{array}{c}\text { neurological } \\
\text { disorder }\end{array}$ & $\begin{array}{l}\text { curative and } \\
\text { prophylactic }\end{array}$ \\
\hline Child 33 & $\begin{array}{l}\text { exchange blood } \\
\text { transfusion }\end{array}$ & $\begin{array}{l}\text { childhood } \\
\text { (1 year) }\end{array}$ & 40 & $\begin{array}{c}\text { chronic } \\
\text { disease } \\
(>23)\end{array}$ & infection & $\begin{array}{l}\text { hemolytic anemia } \\
\text { thrombocytopenia }\end{array}$ & none & none & $\begin{array}{c}\text { curative plasmatherapy } \\
\text { of acute phase }\end{array}$ \\
\hline Child 34 & none & $\begin{array}{l}\text { childhood } \\
\text { (1 year) }\end{array}$ & 11 & $\begin{array}{c}{[0-5]} \\
(1)\end{array}$ & infection & $\begin{array}{l}\text { hemolytic anemia } \\
\text { thrombocytopenia }\end{array}$ & $\begin{array}{c}\text { renal (AKI), } \\
\text { cardiac (atrial } \\
\text { fibrillation) }\end{array}$ & cardiac disorder & curative \\
\hline
\end{tabular}

aHUS: atypical hemolytic uremic syndrome; AKI: acute kidney injury; TMA: thrombotic microangiopathy; TTP: thrombotic thrombocytopenic purpura;

* USS symptoms:

$$
\begin{array}{ll}
\circ & \text { exchange transfusion } \\
\circ & \text { or anemia } \\
\circ & \text { or thrombocytopenia } \\
\circ & \text { or icterus } \\
\circ & \text { or several items together }
\end{array}
$$

** neonatal period from 0 to 28 days, postneonatal period from 28 days to 1 year, childhood $\geq 1$ year

$* * *$ chronic disease defined USS course characterized by no real acute phase or remission phase but chronic bicytopenia requiring prophylactic plasmatherapy.

**** plasmatherapy: curative plasmatherapy of acute phases, or prophylactic FFP infusions, or both. 
Suppl. Table 3. Genetic analysis of ADAMTS13 polymorphisms (SNPs) in 56 patients with Upshaw-Schulman syndrome.

\begin{tabular}{|l|c|c|c|c|c|}
\hline \multirow{2}{*}{ SNPs } & \multicolumn{2}{|c|}{ Child-onset USS } & \multicolumn{2}{c|}{ Adult-onset USS } & gnomAD population \\
\cline { 2 - 6 } & N alleles & $\begin{array}{c}\text { Allele } \\
\text { frequency }\end{array}$ & N alleles & $\begin{array}{c}\text { Allele } \\
\text { frequency }\end{array}$ & Allele frequency \\
\hline c.19C>T (p.Arg7Trp) & 3 & $9 \%$ & 16 & $73 \%$ & $9.1 \%$ \\
\hline c.1342C>G (p.Gln448Glu) & 20 & $59 \%$ & 5 & $23 \%$ & $37.5 \%$ \\
\hline c.1852C>G (p.Pro618Ala) & 4 & $12 \%$ & 5 & $23 \%$ & $6 \%$ \\
\hline c.2195C>T (p.Ala732Val) & 3 & $9 \%$ & 4 & $18 \%$ & $1 \%$ \\
\hline c.2699C>T (p.Ala900Val) & 3 & $9 \%$ & 0 & $0 \%$ & $8.4 \%$ \\
\hline c.3097G>A (p.Ala1033Thr) & 1 & $3 \%$ & 21 & $95 \%$ & $3 \%$ \\
\hline
\end{tabular}

(USS: Upshaw-Schulman syndrome)

All SNPs found in our patients have been previously reported in the literature (Levy et al, Nature 2001): p.Arg7Trp, p.GIn448Glu and p.Ala900Val were predicted to be non-deleterious, whereas p.Ala732Val, p.Ala618Pro and p.Ala1033Thr were predicted to be deleterious (Moatti et al, Blood 2012). 
Legend to suppl. Figure 1. Correlation between ADAMTS13 genotype and ADAMTS13 antigen in 53/56 patients with Upshaw-Schulman syndrome (USS).

ADAMTS13 antigen levels measured by $3 \mathrm{H} 9$-based ELISA assay $(0.03 \mathrm{ug} / \mathrm{mL}$ limit of detection for use in ADAMTS13 conformation ELISA, indicated by dotted black line) is represented as a function of the localization of the amino acid change on ADAMTS13 protein ( $\mathrm{N}$-term or $\mathrm{C}$-term domain for missense mutations, "other" for unpredictable localization linked to truncating mutations) in child-onset (1A) and adult-onset (1B) USS patients.

Similarly, ADAMTS13 antigen is also represented as a function of missense or truncating features of ADAMTS13 mutations in child-onset (1C) and adult-onset (1D) USS patients 
Suppl. Figure 1

A

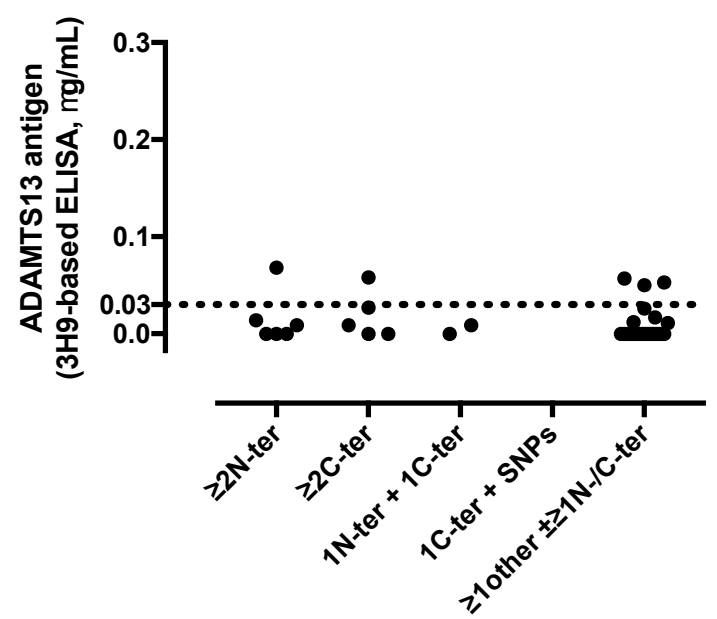

C

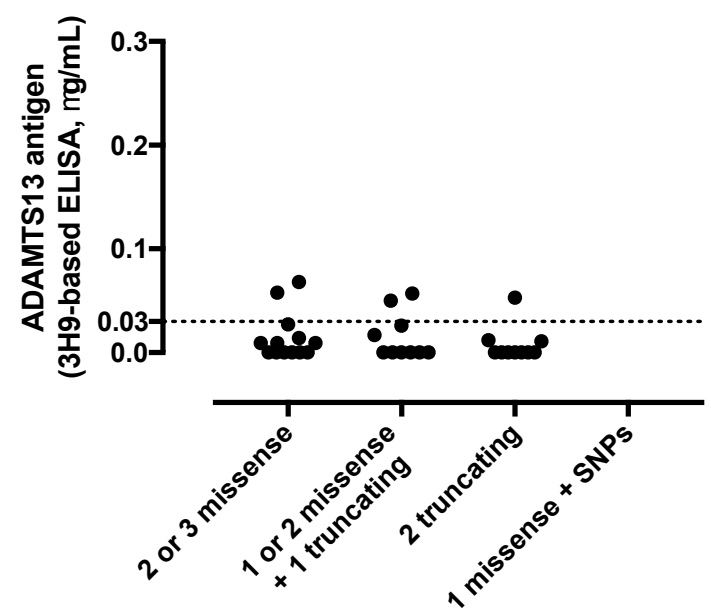

B

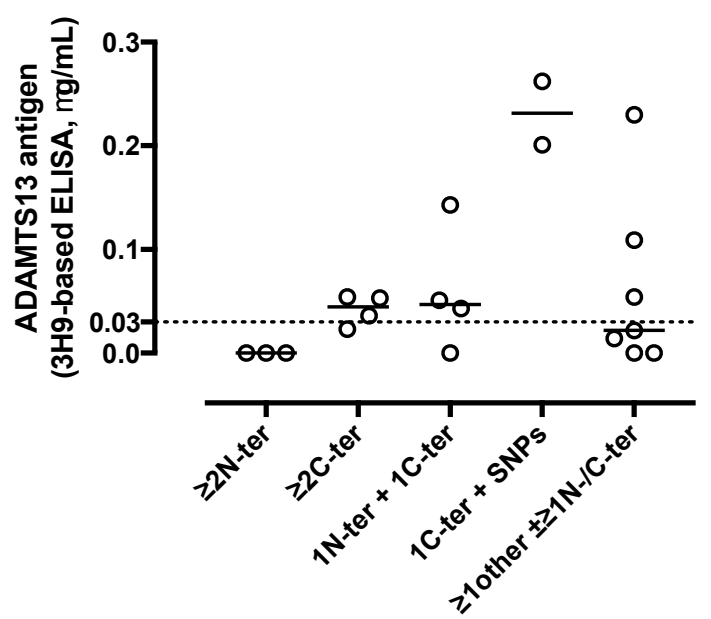

D

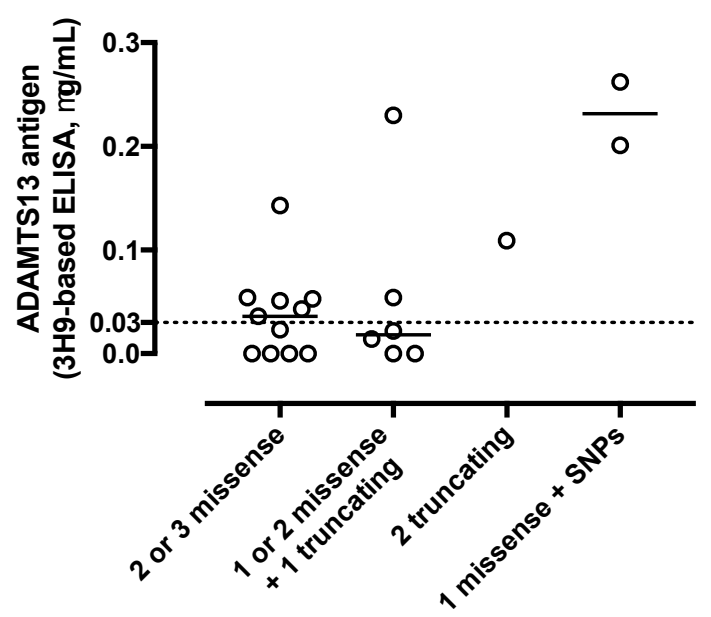




\section{Figure 2}

\section{A. Child-onset USS}

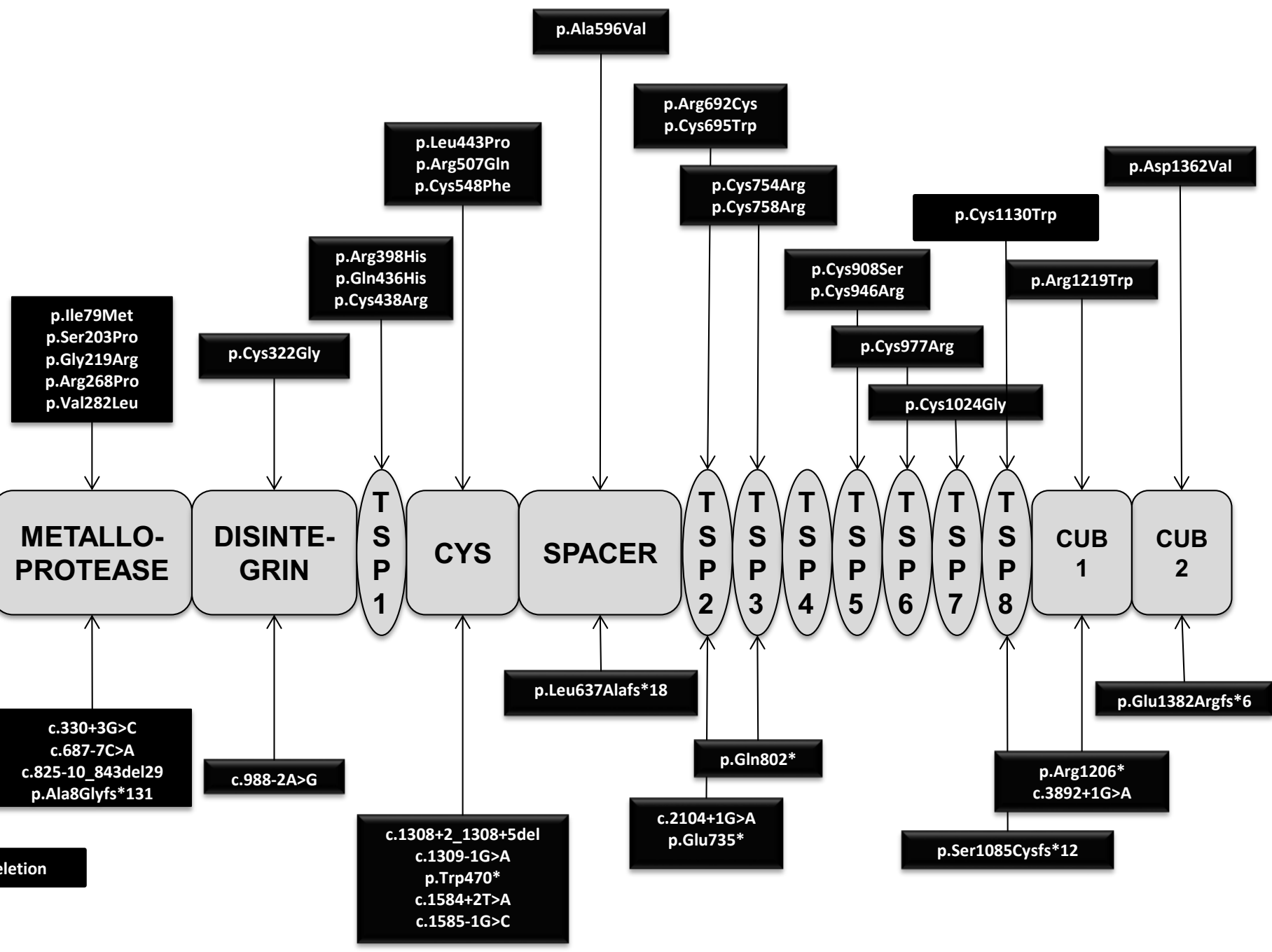

\section{B. Adult-onset USS}

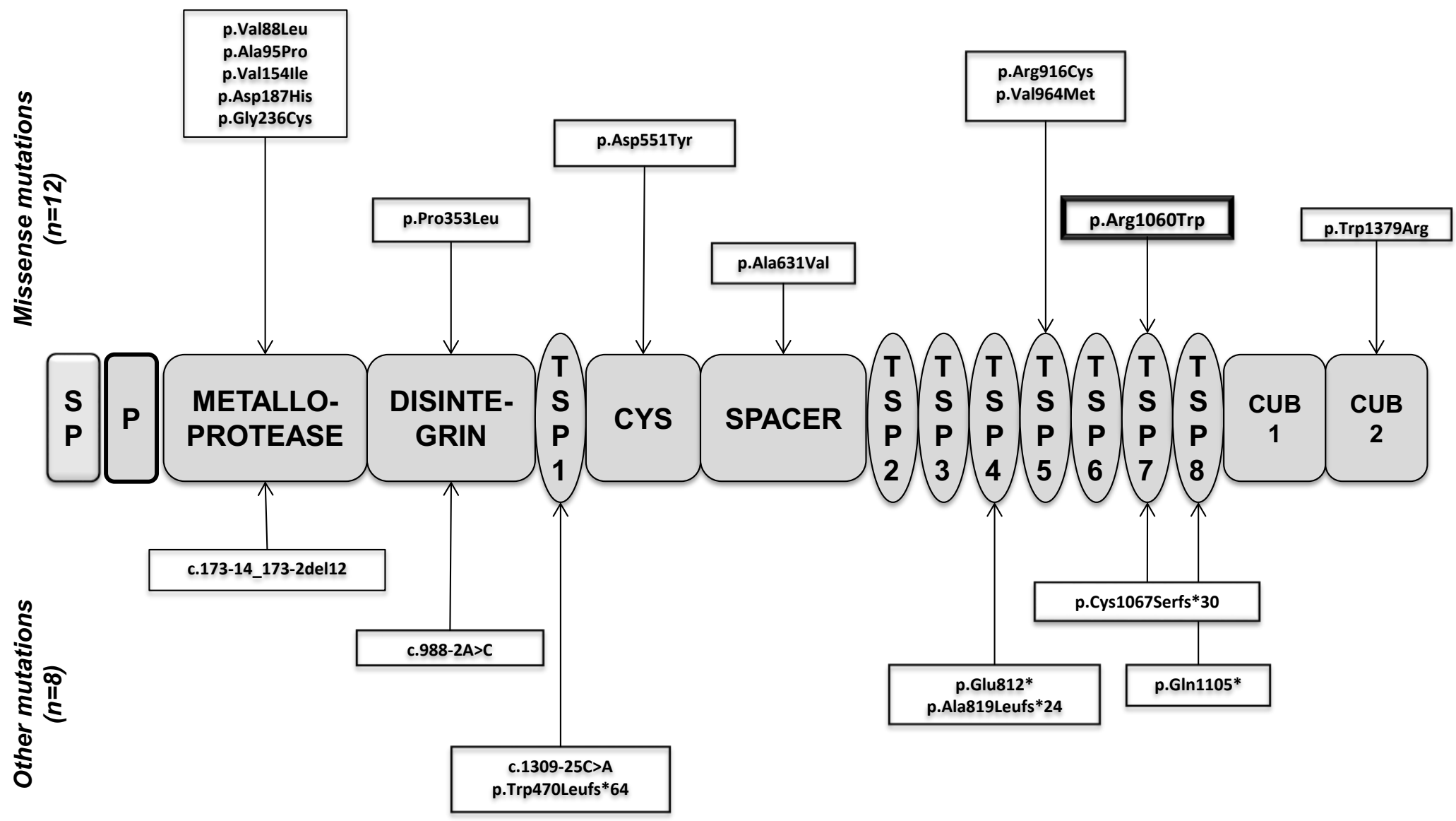


Figure 3

A

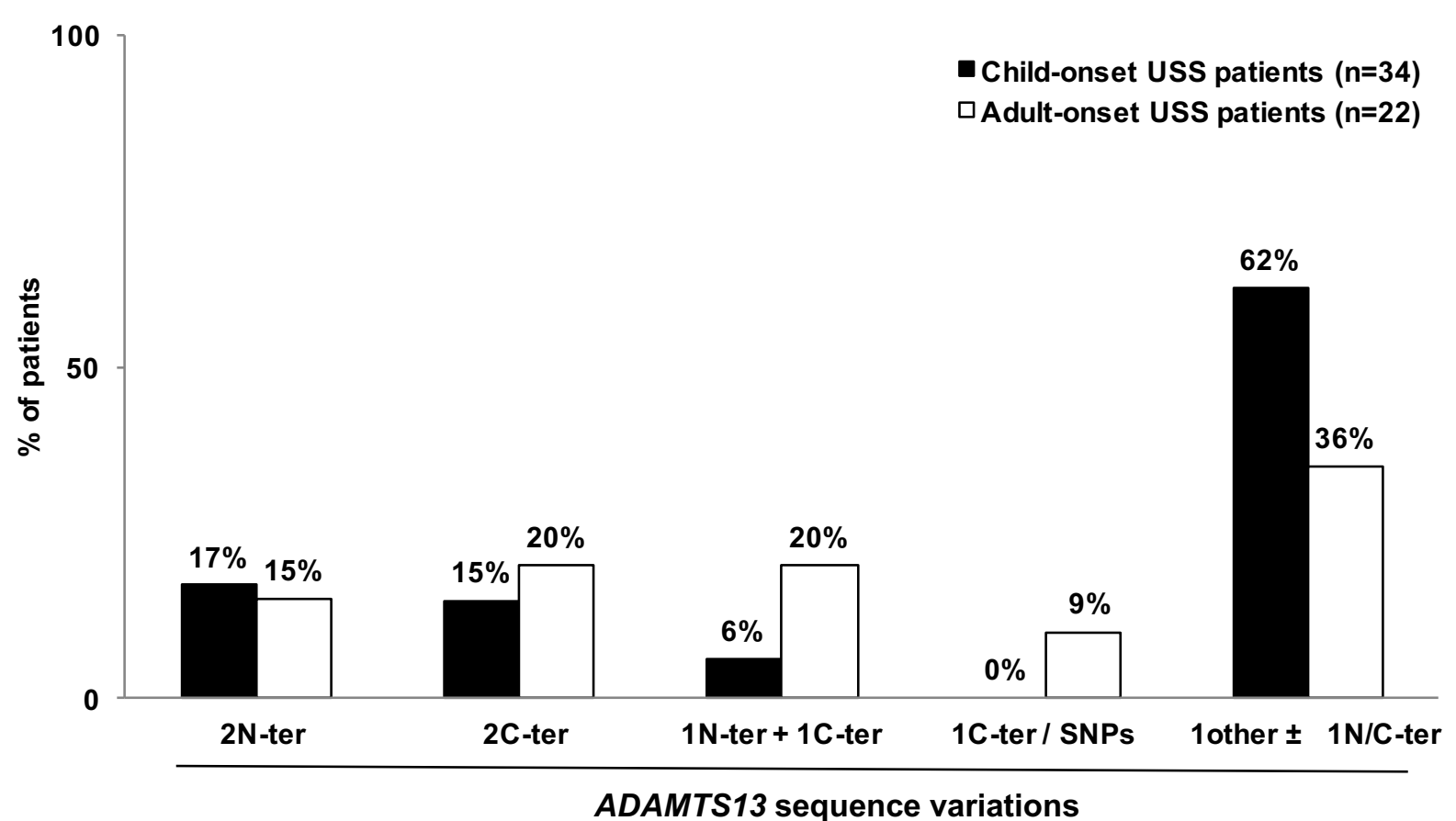

B

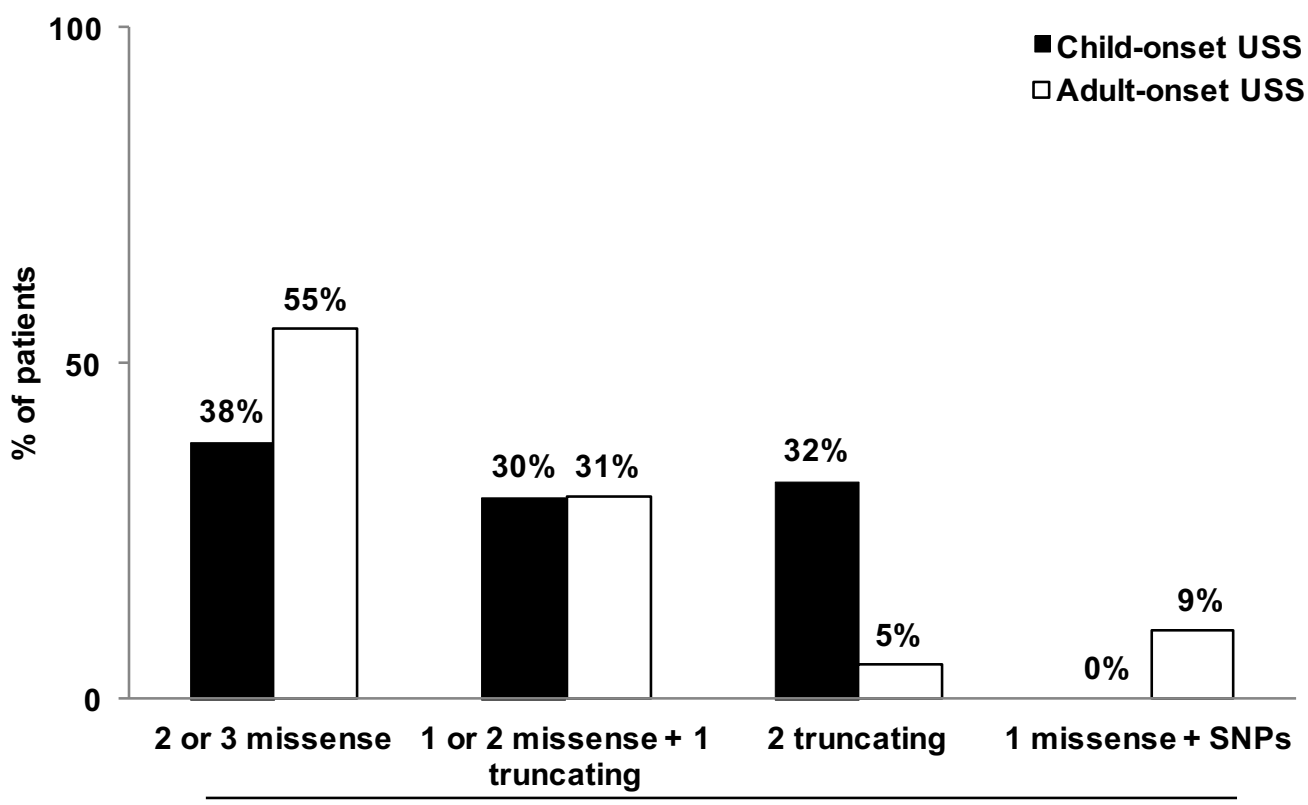

ADAMTS13 sequence variations 
A

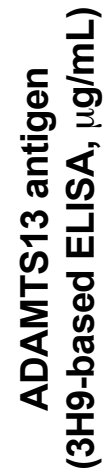

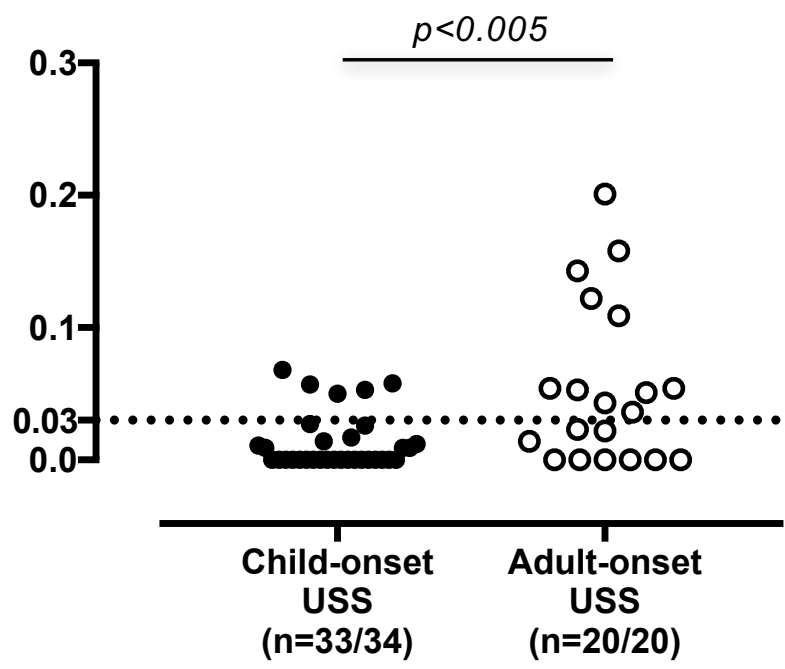

C

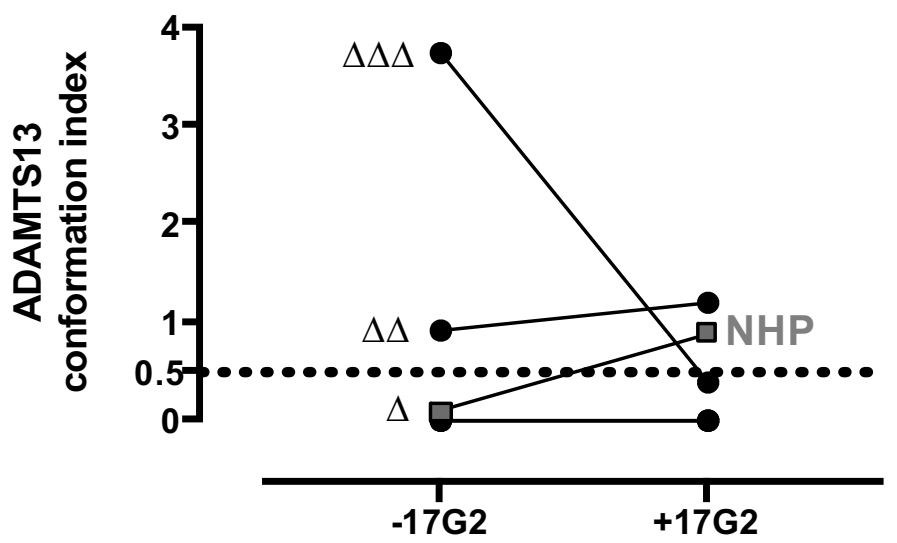

Child-onset USS patients

$(n=5 / 34)$

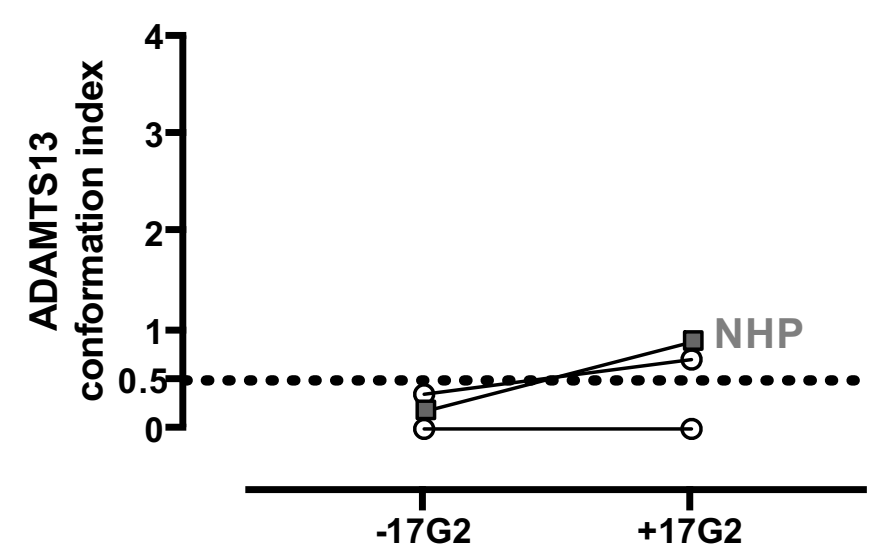

Adult-onset USS patients

$(n=11 / 22)$
B

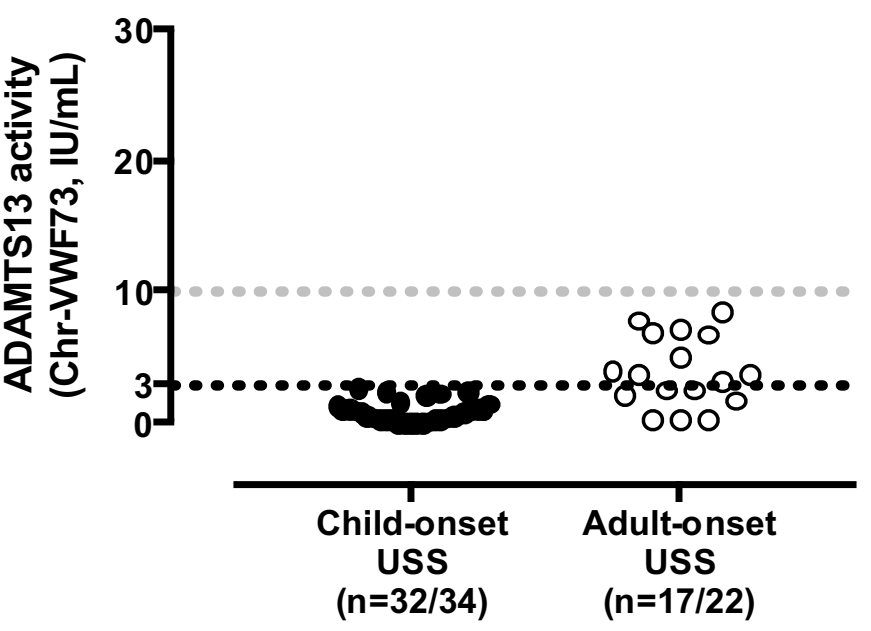

Child-onset USS patients $(n=5)$

ADAMTS13 genotype

$\Delta \Delta \Delta$ p.Arg1206*/p.Arg1206* (CUB1/CUB1)

$\Delta \Delta$ c.1309-1G $>$ A/p.Cys 908 Ser (./TSP1-5)

$\Delta$ c.988-2A>G/p.Asp1362Val (./CUB2)

$\triangle$ p.Ala 596Val/p.Ala 596Val (spacer/spacer)

$\Delta$ p.Cys 1024Gly/p.Cys 1024Gly (TSP1-7/TSP1-7)
Adult-onset USS patients $(n=11)$

ADAMTS13 genotype

$\Delta \Delta$ p.Arg1060Trp/SNPs (n=2) (TSP1-7l.)

$\Delta$ p.Glu812*/p.Arg1060Trp (./TSP1-7)

$\Delta$ p.Pro353Leu/p.Arg1060Trp (Disintegrin/TSP1-7)

$\Delta$ p.Val88Leu/p.Arg1060Trp (Metalloprotease/TSP1-7)

$\Delta$ p.Asp551Tyr/p.Arg1060Trp (Cys-rich/TSP1-7)

$\Delta$ p.Arg1060Trp/p.Arg1060Trp ( $\mathrm{n}=2$ ) (TSP1-7/TSP1-7)

$\Delta$ c.173-14_173-2del12/p.Cys1067Serfs*30 (./TSP1-7)

$\Delta$ p.Arg916Cys/p.Arg1060Trp (TSP1-5/TSP1-7)

$\Delta$ p.Trp470Leufs ${ }^{*} 64$ / p.Arg1060Trp (.ITSP1-7) 


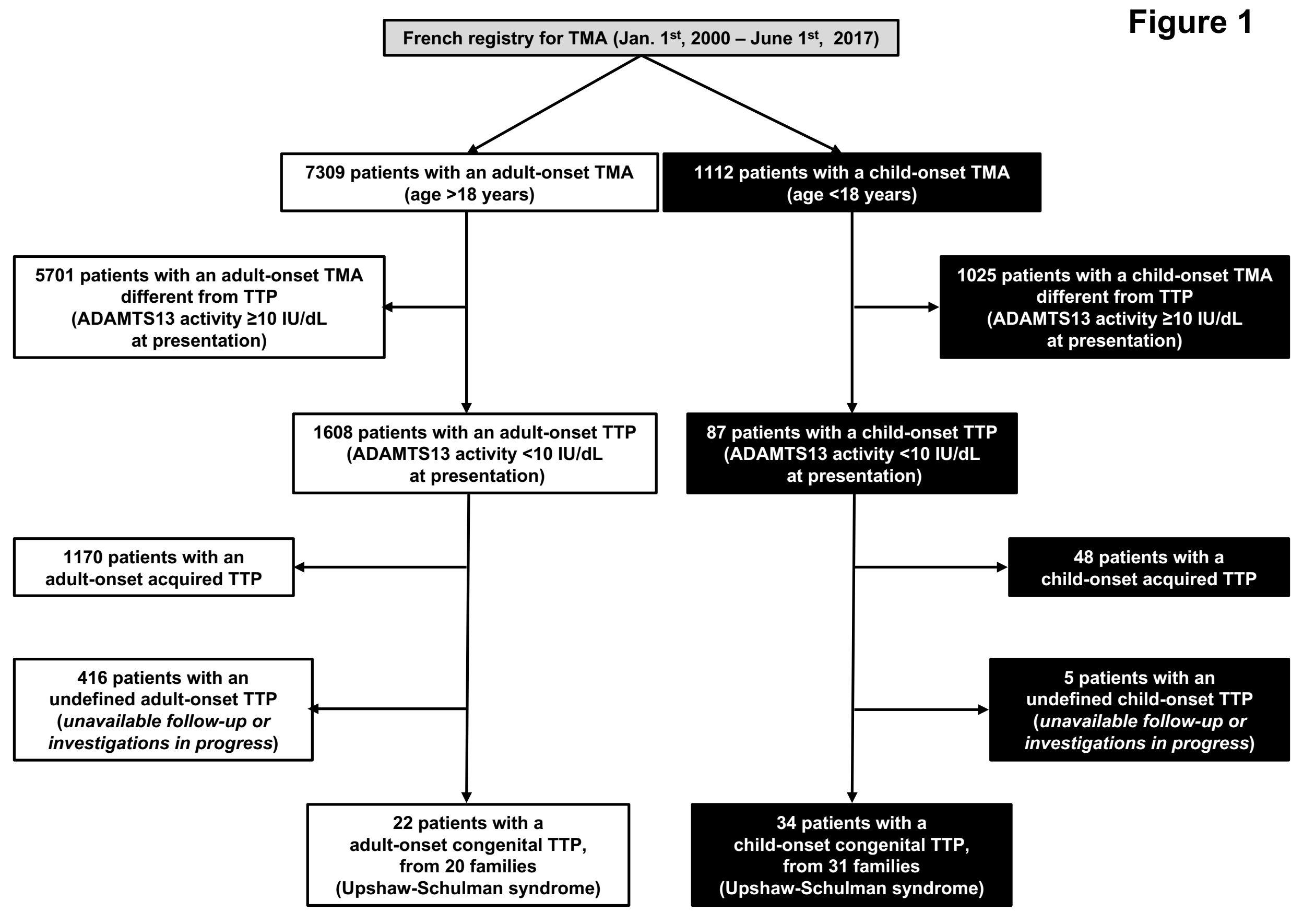

